\title{
Distribution and origin of suspended matter and organic carbon pools in the Tana River Basin, Kenya
}

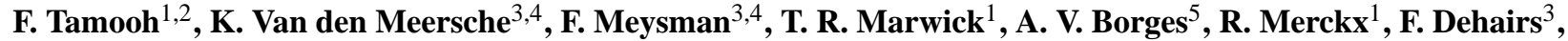 \\ S. Schmidt ${ }^{6}$, J. Nyunja ${ }^{7}$, and S. Bouillon ${ }^{1}$ \\ ${ }^{1}$ Katholieke Universiteit Leuven, Dept. of Earth \& Environmental Sciences, Celestijnenlaan 200E, 3001 Leuven, Belgium \\ ${ }^{2}$ Kenya Wildlife Service, P.O. Box 82144-80100, Mombasa, Kenya \\ ${ }^{3}$ Department of Analytical and Environmental Chemistry, Vrije Universiteit Brussel (VUB), Belgium \\ ${ }^{4}$ Royal Netherlands Institute of Sea Research (NIOZ), Yerseke, The Netherlands \\ ${ }^{5}$ Unité d'Océanographie Chimique, Université de Liège, Belgium \\ ${ }^{6}$ CNRS, UMR5805 EPOC, 33405 Talence Cedex, France \\ ${ }^{7}$ Kenya Wildlife Service, P.O. Box 40241-00100, Nairobi, Kenya
}

Correspondence to: F. Tamooh (fredrick.tamooh@ees.kuleuven.be)

Received: 16 February 2012 - Published in Biogeosciences Discuss.: 8 March 2012

Revised: 25 June 2012 - Accepted: 4 July 2012 - Published: 2 August 2012

\begin{abstract}
We studied patterns in organic carbon pools and their origin in the Tana River Basin (Kenya), in February 2008 (dry season), September-November 2009 (wet season), and June-July 2010 (end of wet season), covering the full continuum from headwater streams to lowland mainstream sites. A consistent downstream increase in total suspended matter (TSM, 0.6 to $7058 \mathrm{mg} \mathrm{l}^{-1}$ ) and particulate organic carbon (POC, 0.23 to $119.8 \mathrm{mg} \mathrm{l}^{-1}$ ) was observed during all three sampling campaigns, particularly pronounced below $1000 \mathrm{~m}$ above sea level, indicating that most particulate matter exported towards the coastal zone originated from the mid and low altitude zones rather than from headwater regions. This indicates that the cascade of hydroelectrical reservoirs act as an extremely efficient particle trap. Although ${ }^{7} \mathrm{Be} /{ }^{210} \mathrm{~Pb}_{\mathrm{xs}}$ ratios/age of suspended sediment do not show clear seasonal variation, the gradual downstream increase of suspended matter during end of wet season suggests its origin is caused by inputs of older sediments from bank erosion and/or river sediment resuspension. During wet season, higher TSM concentrations correspond with relatively young suspended matter, suggesting a contribution from recently eroded material. With the exception of reservoir waters, POC was predominantly of terrestrial origin as indicated by generally high POC: chlorophyll $a$ (POC:Chl $a$ ) ratios (up to $\sim 41000)$. Stable isotope signatures of POC $\left(\delta^{13} \mathrm{C}_{\mathrm{POC}}\right)$ ranged between -32 and $-20 \%$ and increased downstream,
\end{abstract}

reflecting an increasing contribution of C4-derived carbon in combination with an expected shift in $\delta^{13} \mathrm{C}$ for $\mathrm{C} 3 \mathrm{veg}-$ etation towards the more semi-arid lowlands. $\delta^{13} \mathrm{C}$ values in sediments from the main reservoir $(-19.5$ to $-15.7 \%$ ) were higher than those found in any of the riverine samples, indicating selective retention of particles associated with $\mathrm{C} 4$ fraction. Dissolved organic carbon (DOC) concentrations were highest during the end of wet season $\left(2.1\right.$ to $\left.6.9 \mathrm{mgl}^{-1}\right)$, with stable isotope signatures generally between -28 and $-22 \%$. A consistent downstream decrease in $\%$ organic carbon (\% OC) was observed for soils, riverine sediments, and suspended matter. This was likely due to better preservation of the organic fraction in colder high altitude regions, with loss of carbon during downstream spiraling. $\delta^{13} \mathrm{C}$ values for soil and sediment did not exhibit clear altitudinal patterns, but values reflect the full spectrum from $\mathrm{C} 3$-dominated to C4-dominated sites. Very low ratios of organic carbon to mineral surface area (OC:SA) were found in reservoir sediments and suspended matter in the lower Tana River, indicating that these are stable OC pools which have undergone extensive degradation. Overall, our study demonstrates that substantial differences occur in both the quantities and origin of suspended sediments and organic carbon along the river profile in this tropical river basin, as well as seasonal differences in the mechanisms causing such variations. 


\section{Introduction}

Rivers play an important role in the global carbon (C) cycle, and process $\sim 2.7 \mathrm{PgC}$ annually, of which $\sim 0.9 \mathrm{PgC} \mathrm{yr}^{-1}$ is estimated to reach oceans (Cole et al., 2007; Aufdenkampe et al., 2011). Rivers do not merely transport $C$ from the terrestrial biome to the oceanic environment, but also bury and process organic matter, generally acting as a source of $\mathrm{CO}_{2}$ to the atmosphere (Cole and Caraco, 2001; Mayorga et al., 2005; Cole et al., 2007). Although the riverine C flux may be small compared to the gross global fluxes between ocean-atmosphere $\left(90 \mathrm{Pg} \mathrm{Cyr}^{-1}\right)$ and terrestrial-atmosphere (120 $\mathrm{Pg} \mathrm{C} \mathrm{yr}^{-1}$ ) interfaces (Schlünz and Schneider, 2000; Prentice et al., 2001; Houghton, 2004; Sabine et al., 2004), the fluvial $\mathrm{C}$ flux transport is of the same order as the respective net ecosystem production $\left(2.2 \mathrm{Pg} \mathrm{C} \mathrm{yr}^{-1}\right)$ (Cole and Caraco, 2001; Cole et al., 2007; Battin et al., 2008; Aufdenkampe et al., 2011).

Riverine systems transport $\mathrm{C}$ mainly as DOC, POC and dissolved inorganic C (DIC). Globally, rivers discharge into the world's oceans approximately $0.5 \mathrm{PgC}^{-1}$ as DIC and about $0.4 \mathrm{Pg} \mathrm{Cyr}^{-1}$ as organic C (OC), with about one-half each as POC and DOC (Meybeck, 1993; Probst et al., 1994; Ludwig et al., 1996; Ludwig and Probst, 1998; Schlünz and Schneider, 2000). Fluvial C fluxes may differ strongly among individual rivers due to the large variation in variables such as catchment slopes, vegetation, geology, climate and size (Hope et al., 1994). The global sediment yield of rivers is estimated at $160-180 \mathrm{t} \mathrm{km}^{-2} \mathrm{yr}^{-1}$ in pre-dammed conditions (Vörösmarty et al., 2003). However, most current C flux estimates do not account for human impact such as retention of material in reservoirs; hence, actual sediment load and POC transport to the oceans may be lower because of increased damming of rivers (Vörösmarty et al., 2003; Syvitski et al., 2005).

Riverine POC is mainly derived from soils, litterfall and primary production while DOC arises from degradation of organic matter in the soil, leaching of plant litter and, to a lesser degree, from the contribution of autochthonous biological processes occurring in the stream (Meybeck, 1993; Ludwig et al., 1996; Finlay and Kendall, 2007). Globally, riverine DOC fluxes are dependent on drainage intensity, basin slope and to a larger extent, the amount of $\mathrm{C}$ stored in soils, while POC on the other hand is a function of TSM fluxes which principally depend on drainage intensity, rainfall intensity and basin slope (Ludwig et al., 1996). In the majority of rivers, the POC content of TSM ranges between 1 and $20 \%$, but it can exceptionally reach $0.5 \%$ for highly turbid rivers, or values greater than $20 \%$ for lowland rivers draining swamps (Meybeck, 1982, 1993; Ittekkot, 1988; Ludwig et al., 1996; Mayorga et al., 2010).

The origin of riverine organic $\mathrm{C}$ is commonly categorized as either allochthonous-derived from terrestrial organic matter or autochthonous-derived from in-situ biological production (Hope et al., 1994; Finlay and Kendall, 2007). According to the river continuum concept (Vannote et al., 1980), the relative contribution of different sources to total $\mathrm{OC}$ varies with stream size, where allochthonous $\mathrm{C}$ is expected to be important in first order streams, giving way to autochthonous production downstream as the stream size increases. As turbidity increases in large or disturbed rivers, light limits autotrophic production again, and hence allochthonous forms of $\mathrm{C}$ are expected to dominate energy flow (Vannote et al., 1980). Besides the river continuum concept (Vannote et al., 1980), the serial discontinuity concept (Ward and Stanford, 1983) accounts for disturbances in river flow such as congestion by dams, while the flood pulse concept (Junk et al., 1989) accounts for the exchange of material with surrounding flooded plains. Tropical rivers account for $60 \%$ of estimated C flux and $34 \%$ of the sediment delivery to the global oceans (Ludwig et al., 1996; Schlünz and Schneider, 2000). In view of the increasingly recognized importance of freshwater ecosystems in the C cycle (Cole et al., 2007; Battin et al., 2008; Tranvik et al., 2009; Aufdenkampe et al., 2011), and considering the disproportionate role tropical rivers have in global riverine $\mathrm{C}$ export, the biogeochemistry of tropical rivers merits particular attention. Given the relative scarcity of data, this requires both a better quantification of material (export) fluxes, as well as multi-proxy studies on the origin and processing of organic matter. The quantification of bulk concentrations of TSM, POC, DOC, allow the quantification of export fluxes, while stable isotopes and radioisotopes provide information on sources and time-scales of processing, respectively.

Carbon stable isotope signatures $\left(\delta^{13} \mathrm{C}\right)$ are dependent on the photosynthetic pathway, and thus differ substantially between terrestrial C3 plants (and C3 plant-dominated soils) and $\mathrm{C} 4$ plants (or $\mathrm{C} 4$ plant-dominated soils), which have typical $\delta^{13} \mathrm{C}$ value of about -28 and $-13 \%$, respectively (Still and Powell, 2010; Kohn, 2010). Freshwater autotrophs such as phytoplankton can have a wide range of $\delta^{13} \mathrm{C}$ signatures ( -42 to $-19 \%$ according to Finlay and Kendall, 2007), depending e.g. on the $\delta^{13} \mathrm{C}$ values of DIC.

Thus, stable isotopes have frequently been used, in combination with other proxies such as elemental ratios (POC: $\mathrm{PN}$ ) and/or POC: Chl $a$ ratios, to constrain the relative contribution of different organic matter sources (autochthonous vs. allochthonous), and to understand $\mathrm{C}$ fluxes and the fate of terrigenous $\mathrm{C}$ in river systems (Kendall et al., 2001; Finlay and Kendall, 2007). Radionuclides, particularly ${ }^{7} \mathrm{Be},{ }^{210} \mathrm{~Pb}$ and ${ }^{137} \mathrm{Cs}$, have recently been applied as tracers to identify source regions of sediments, quantify residence and settling times of particles within a given river basin, as well as understanding aspects of fluvial sediment erosion, transport, deposition and resuspension (Matisoff et al., 2002, 2005). Both ${ }^{7} \mathrm{Be}$ $\left(\mathrm{t}_{1 / 2}=53.3 \mathrm{~d}\right)$ and ${ }^{210} \mathrm{~Pb}\left(\mathrm{t}_{1 / 2}=22.3 \mathrm{yr}\right)$ are delivered to the Earth surface through wet and dry fallout and both elements sorb strongly to particles, hence, qualifying as tracers of sediment origin (Bonniwell et al., 1999; Matisoff et al., 2002; Saari et al., 2010). The ratio of ${ }^{7} \mathrm{Be} /{ }^{210} \mathrm{~Pb}_{\mathrm{xs}}$ in suspended 
matter reflects the age of sediment (i.e. the time since the sediment received both ${ }^{7} \mathrm{Be}$ and ${ }^{210} \mathrm{~Pb}_{\mathrm{xs}}$ from atmospheric deposition) and can be used to quantify the proportion of resuspended bottom material in the water column (Olsen et al., 1986). Thus, a decrease in the ${ }^{7} \mathrm{Be} /{ }^{210} \mathrm{~Pb}_{\mathrm{xs}}$ ratio reflects an increase in the time since the sediment was "tagged" with atmospherically derived ${ }^{7} \mathrm{Be}$ and ${ }^{210} \mathrm{~Pb}_{\mathrm{xs}}$, since ${ }^{7} \mathrm{Be}$ has a much shorter half-life than ${ }^{210} \mathrm{~Pb}$. Alternatively, a decrease in this ratio may reflect dilution of ${ }^{7} \mathrm{Be}$-rich sediment with ${ }^{7}$ Be-deficient old sediment (Matisoff et al., 2005).

The present study focuses on the distribution and origin of OC pools in the Tana River, Kenya, as regulated by reservoirs and along a longitudinal gradient. It is based on four sampling campaigns which include three basin-wide surveys covering different seasons (dry season - February 2008, wet season - September-November 2009, and end of wet season - June-July 2010) and one follow-up campaign in September 2011. These data provide one of the most complete studies quantifying and characterising riverine $\mathrm{OC}$ at the scale of an entire tropical river catchment.

\section{Materials and methods}

\subsection{Study area}

The Tana River is the longest river in Kenya $(\sim 1100 \mathrm{~km})$, with a total catchment area of $\sim 96000 \mathrm{~km}^{2}$ (Fig. 1a). The basin experiences a bimodal hydrological cycle, with long rains between March and May, and short rains between October and December (Fig. 2). The river system can be separated into two main parts, here referred to as the "Tana headwaters" and the "lower main Tana" (Fig. 1b). The Tana headwaters encompass a set of small mountainous streams that form the perennial source of the Tana River, and which originate from the Aberdares Range in the central highlands of Kenya, the highlands around Mount Kenya, and the Nyambene Hills in eastern Kenya (Fig. 1a). The lower main Tana encompasses the section downstream of the Nyambene Hills, where the river continues for about $700 \mathrm{~km}$ through semi-arid plains. Along this stretch, tributaries only discharge in short pulses during the wet season. As a result, the lower main Tana forms a single transport channel during the dry season, delivering material to the Indian Ocean (Maingi and Marsh, 2002). Along the lower main Tana, extensive floodplains are found between the towns of Garissa and Garsen (Fig. 1a). Yet, flooding has been irregular in recent decades, as the river flow is regulated by five hydroelectric dams upstream (Maingi and Marsh, 2002). The associated reservoirs have a combined surface area of $150 \mathrm{~km}^{2}$, and a substantial amount of sediment is trapped behind these dams (Dunne and Ongweny, 1976; Brown and Schneider, 1998). The basin experiences variable rainfall patterns, decreasing from the headwaters $(>3050 \mathrm{~m}$, annual precipitation $\sim 1800 \mathrm{~mm} \mathrm{yr}^{-1}$ ), upper highlands $(2450-3050 \mathrm{~m}$, annual precipitation $\sim 2200 \mathrm{~mm} \mathrm{yr}^{-1}$ ), mid-altitude catchment (1850-900 m, annual precipitation between 900 and $2000 \mathrm{~mm} \mathrm{yr}^{-1}$ ), to the lower semi-arid Tana catchment (900$10 \mathrm{~m}$ ) which receives $450-900 \mathrm{~mm} \mathrm{yr}^{-1}$ (Brown and Schneider, 1998). The mean annual river discharge is $156 \mathrm{~m}^{3} \mathrm{~s}^{-1}$ as measured at Garissa gauging station (data from the Global River Discharge Database, available on http://daac.ornl.gov/ RIVDIS/rivdis.shtml). The average river discharge measured at Garissa station during the wet season $\left(208.5 \mathrm{~m}^{3} \mathrm{~s}^{-1}\right.$; October and November 2009) was 1.7 and 1.4 times higher than during the dry season $\left(122.9 \mathrm{~m}^{3} \mathrm{~s}^{-1}\right.$; February 2008) and end-of-wet-season (145.2 $\mathrm{m}^{3} \mathrm{~s}^{-1}$; June and July 2010), respectively (Fig. 2). The high-altitude headwaters (Aberdares, Mt. Kenya) are characterized by montane forest vegetation and moorlands at the highest elevations, giving way to more intense agricultural activities in mid altitude regions. The semi-arid lower Tana is dominated by open to wooded savannah grassland, with some riverine gallery forests along the Tana River.

\subsection{Sampling and analytical techniques}

Water, sediment and soil sampling was carried out during three campaigns in February 2008 (dry season), SeptemberNovember 2009 (wet season), and June-July 2010 (end of wet season) (Fig. 2), with additional sampling of riverbank sediments in September 2011. Samples were taken throughout the river basin (Fig. 1 - Supplement Table 1), and sampling sites included a subset of small streams in the headwater regions, an approximately equidistant set of locations along the main lower Tana, and two of the five hydro-electric reservoirs (Masinga and Kamburu). The first field survey in February 2008 only covered a subset of these field sites, for which the water column data have already been presented in Bouillon et al. (2009), and only the data on soils and riverine sediments are further detailed here. In both the 2009 and 2010 campaigns, an extensive basin-wide survey was carried out. During the follow-up fieldtrip in September 2011, depth profiles of riverbank soils were collected at several sites along the lower Tana River.

Water samples were taken with a Niskin bottle at $\sim 0.5 \mathrm{~m}$ below the water surface, or using a bucket when sampling from bridges along the main river. Samples for TSM were taken by filtration of a known volume of surface water on $47 \mathrm{~mm} \mathrm{GF} / \mathrm{F}$ filters (nominal porosity $=0.7 \mu \mathrm{m}$ ), which were pre-weighed and pre-combusted $\left(4 \mathrm{~h}\right.$ at $\left.450{ }^{\circ} \mathrm{C}\right)$, and then dried and re-weighed after filtration. Samples for POC, particulate nitrogen (PN), and $\delta^{13} \mathrm{C}_{\mathrm{POC}}$ were obtained in a similar way by filtering a known volume of surface water on pre-combusted $25 \mathrm{~mm}$ GF/F filters $(0.7 \mu \mathrm{m})$ and drying. In the laboratory, these filters were exposed to $\mathrm{HCl}$ fumes for $4 \mathrm{~h}$ to remove inorganic $\mathrm{C}$, re-dried and packed in $\mathrm{Ag}$ cups.

Topsoil samples (surface $0-5 \mathrm{~cm}$ layer) were collected at all sampling sites (except the Masinga and Kamburu reservoirs), slightly upstream from the water sampling location 


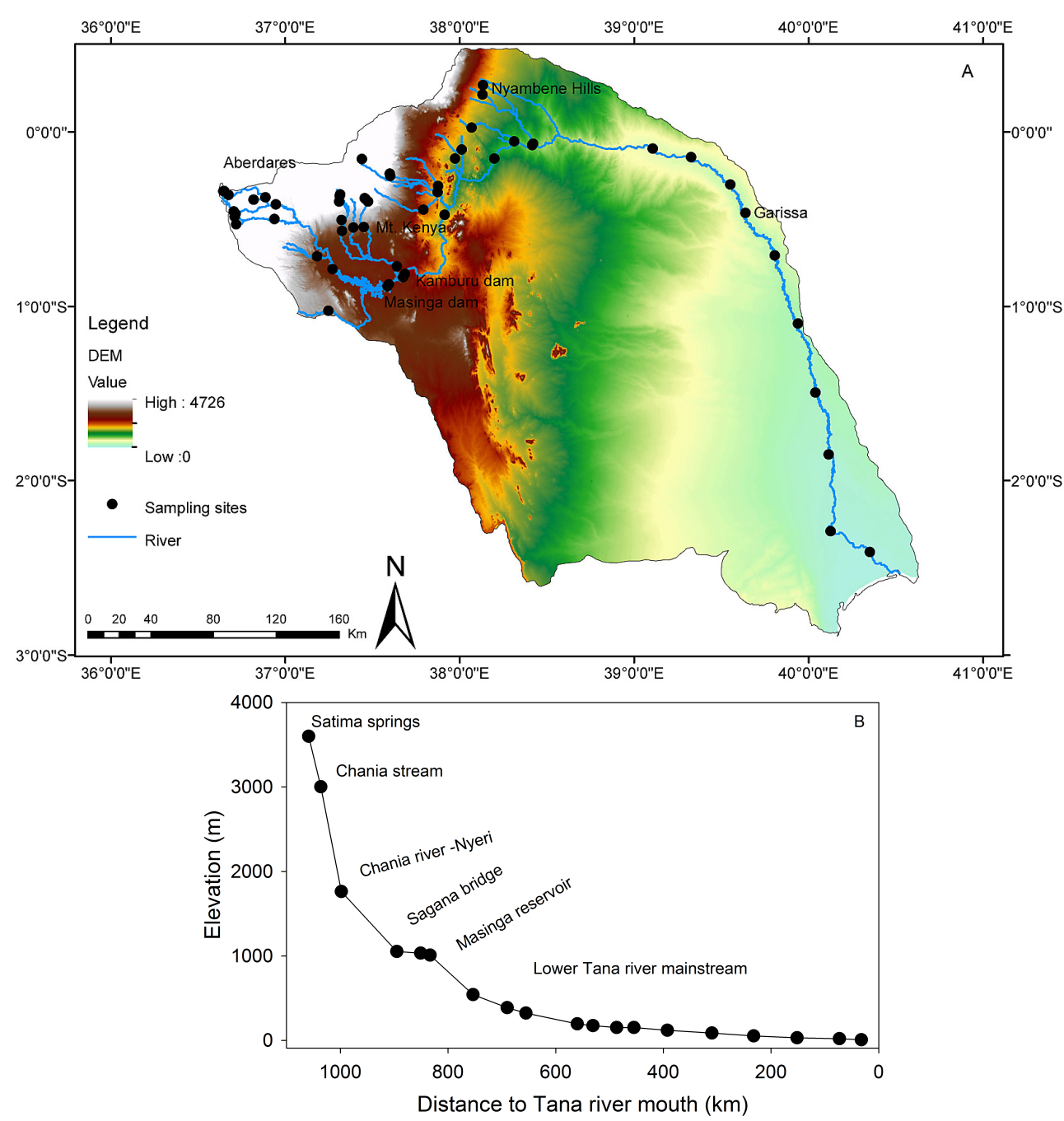

Fig. 1. (A) Digital Elevation Model (DEM) of the Tana River Basin, which consists of two main geographical units, the Tana headwaters and the main lower Tana. The 57 sampling sites are indicated by black dots. (B) Profile of the Tana River from headwaters to Tana mouth. Sampling stations for the lower Tana River are indicated, as well as a selected number of headwater sampling sites to show their overall position.

and $\sim 10 \mathrm{~m}$ from the riverbank. Along the main Tana River, riverbed sediments were sampled with a Van Veen grab, while in the shallow headwater streams, sediment was directly collected into sample tubes. An unusually dry period preceded the fieldwork in September-October 2009 and led to historically low water levels in the Masinga reservoir. This enabled easy access to the reservoir bottom. Three short sediment cores (up to $30 \mathrm{~cm}$ ) were taken at the lowest sites accessible, and within the zone where clear, thick sediment deposits were present. In the same campaign, the Van Veen grab was used to retrieve surface sediment from the Kamburu reservoir. All soil and sediment samples were stored in liquid $\mathrm{N}_{2}$ during transport, and upon return to the laboratory, they were preserved at $-20^{\circ} \mathrm{C}$ until further analysis. In the laboratory, sediment and soil samples were dried, ground and homogenized using a mortar and pestle. A weighed subsam- ple was transferred into a $\mathrm{Ag}$ cup to which a $10 \% \mathrm{HCl}$ solution was added to remove all carbonates. The samples were then dried at $60^{\circ} \mathrm{C}$ for $24 \mathrm{~h}$, and if necessary, the procedure was repeated.

POC, PN, and $\delta^{13} \mathrm{C}_{\mathrm{POC}}$ from filters, soil and sediment samples were determined on a Thermo elemental analyzerisotope ratio mass spectrometer (EA-IRMS) system (various configurations, either Flash1112, FlashHT with Delta+XL or DeltaV Advantage), using the thermal conductivity detector (TCD) signal of the elemental analyzer (EA) to quantify POC and PN, and by monitoring 44, 45, and $46 \mathrm{~m} / \mathrm{z}$ signal on the isotope-ratio mass spectrometer (IRMS). Quantification and calibration of $\delta^{13} \mathrm{C}$ data were performed with IAEA-C6 and acetanilide which was internally calibrated vs. international standards. Reproducibility of $\delta^{13} \mathrm{C}_{\mathrm{POC}}$ measurements was typically better than $\pm 0.2 \%$, while relative standard 


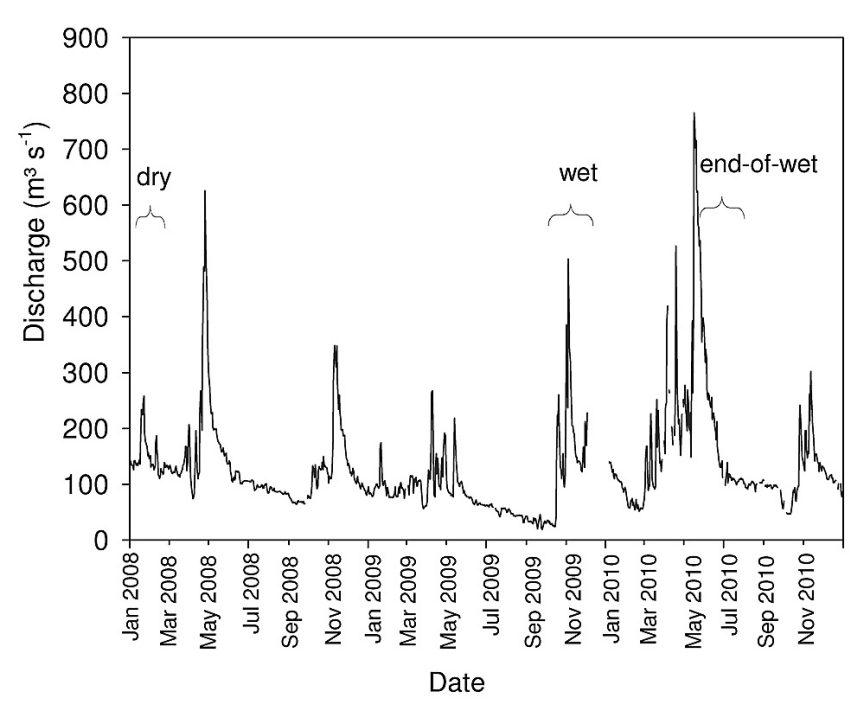

Fig. 2. Discharge measurements for the Tana River (2008-2010) as recorded at Garissa station (data source: Water Resource Management Authority). Brace brackets indicate the duration of the three field investigations.

deviations for calibration standards for POC and PN measurements were typically $<2 \%$ and always $<5 \%$. POC: PN ratios are presented on a weight: weight basis.

Samples for DOC and $\delta^{13} C_{D O C}$ were obtained by prefiltering surface water through pre-combusted $\mathrm{GF} / \mathrm{F}$ filters $(0.7 \mu \mathrm{m})$, with further filtration through $0.2 \mu \mathrm{m}$ syringe filters, and were preserved with $\mathrm{H}_{3} \mathrm{PO}_{4}$ in glass vials with teflon-coated screw caps. DOC and $\delta^{13} \mathrm{C}_{\mathrm{DOC}}$ were measured with either a customized Thermo HiperTOC coupled to a Delta+XL IRMS (Bouillon et al., 2006), or by manual injection in a Thermo IsoLink HPLC-IRMS (similar to the method described in Albéric, 2011). Samples for pigment analysis were obtained by filtering a known volume of surface water on pre-combusted $47 \mathrm{~mm} \mathrm{GF/F} \mathrm{filters,} \mathrm{which}$ were immediately packed in cryotubes and stored in liquid $\mathrm{N}_{2}$. Upon return to the laboratory, these were stored at $-20^{\circ} \mathrm{C}$ until further analysis. Pigments were extracted in $10 \mathrm{ml}$ acetone : water mixture $(90: 10)$, and a subsample was separated by HPLC on a C18 reverse phase column (Bouillon et al., 2009). Calibration was performed with working standards prepared from commercially available pure compounds.

Surface area (SA) measurements were made on 200$600 \mathrm{mg}$ freeze-dried and homogenized samples of soils, sediments and TSM using multi-point Brunauer-Emmet-Teller adsorption isotherms (Brunauer et al., 1938). Measurements were made using a 25 Quantachrome NOVA 3000 SA analyzer, and verified with BCR-173 (Institute for Reference Materials and Measurements).

Samples for radionuclide analysis were obtained by filtering a known volume of surface water on $102 \mathrm{~mm}$ polycarbonate membrane filters. The activities of ${ }^{7} \mathrm{Be},{ }^{210} \mathrm{~Pb}$ and
${ }^{226} \mathrm{Ra}$ were determined on the dried suspended matter using a low background-high efficiency well type $\gamma$-counter placed in a lead shield and protected from cosmic rays using an anti-cosmic shielding made of plastic scintillators (Schmidt et al., 2009). Standards used for calibration of the $\gamma$-detector were IAEA standards (RGU-1; RGTh-1; IAEA314). ${ }^{7} \mathrm{Be}$ values were corrected for radioactive decay that occurred between sample collection and counting. Excess ${ }^{210} \mathrm{~Pb}\left({ }^{210} \mathrm{~Pb}_{\mathrm{xs}}\right)$ was calculated by subtracting the activity supported by parent isotope ${ }^{226} \mathrm{Ra}$ from the total activity measured in particles. The ${ }^{7} \mathrm{Be} /{ }^{210} \mathrm{~Pb}_{x s}$ AR can be used to calculate the age of the sediments or the fraction of new sediments (Matisoff et al., 2005):

Age $=\frac{1}{\left(\lambda_{7 \mathrm{Be}}-\lambda_{210 \mathrm{~Pb}}\right)} \ln \left(\mathrm{AR}_{0} / \mathrm{AR}\right)$
$\%$ new sediment $=\left(\mathrm{AR} / \mathrm{AR}_{0}\right) \times 100$

where $\lambda^{7} \mathrm{Be}$ and $\lambda^{210} \mathrm{~Pb}$ are the decay constants of ${ }^{7} \mathrm{Be}$ $\left(0.013 \mathrm{~d}^{-1}\right)$ and ${ }^{210} \mathrm{~Pb}\left(8.509 \times 10^{-5} \mathrm{~d}^{-1}\right)$. AR and $\mathrm{AR}_{0}$ are the ${ }^{7} \mathrm{Be} /{ }^{210} \mathrm{~Pb}_{\mathrm{xs}}$ AR of suspended particles and of the atmospheric fallout, respectively. In the absence of direct measurements in the study area, we estimated a ${ }^{7} \mathrm{Be} /{ }^{210} \mathrm{~Pb}_{\mathrm{xs}}$ ratio of 12 for atmospheric fallout, based on literature data (Liu et al., 2001; Saari et al., 2010). While this places an uncertainty on the absolute estimates of the sediment age or \% new sediment, it does not affect relative variations in these estimates.

\section{Results}

\subsection{Total suspended matter and particulate organic carbon}

The full dataset is available as Supplement Tables 1-6. The TSM concentrations recorded during the dry season in 2008 ( 0.6 to $483 \mathrm{mg} \mathrm{l}^{-1}$ ) showed a similar range as during the end of wet season conditions in 2010 ( 1 to $471 \mathrm{mg} \mathrm{l}^{-1}$ ), while the range during the wet season was one order of magnitude larger ( 2 to $7058 \mathrm{mgl}^{-1}$ ), with the highest values obtained in the lower main Tana. Paired t-tests confirm that TSM values were similar during dry season and end of wet season datasets $(p>0.05)$, but significantly higher during the wet season campaign. In the dry season campaign of 2008 , there is consistent increase in TSM in the lower main Tana, and this pattern is basically replicated in 2010 . In the wet season campaign of 2009, TSM concentrations are an order of magnitude higher, and show no trend along the lower Tana River axis (Pearson correlation, $p>0.05$; Fig. 3a). In the headwater regions, TSM shows strong variability between streams in all campaigns with exceptionally high values in selected tributaries (Muringato, Thanandu, Mathioya, Mutonga and Maara) during the wet season (Supplement Table 1; Fig. 3a).

Concentrations of POC during the wet season $(0.23$ to $119.8 \mathrm{mg}^{-1}$ ) were much higher than during the dry season 


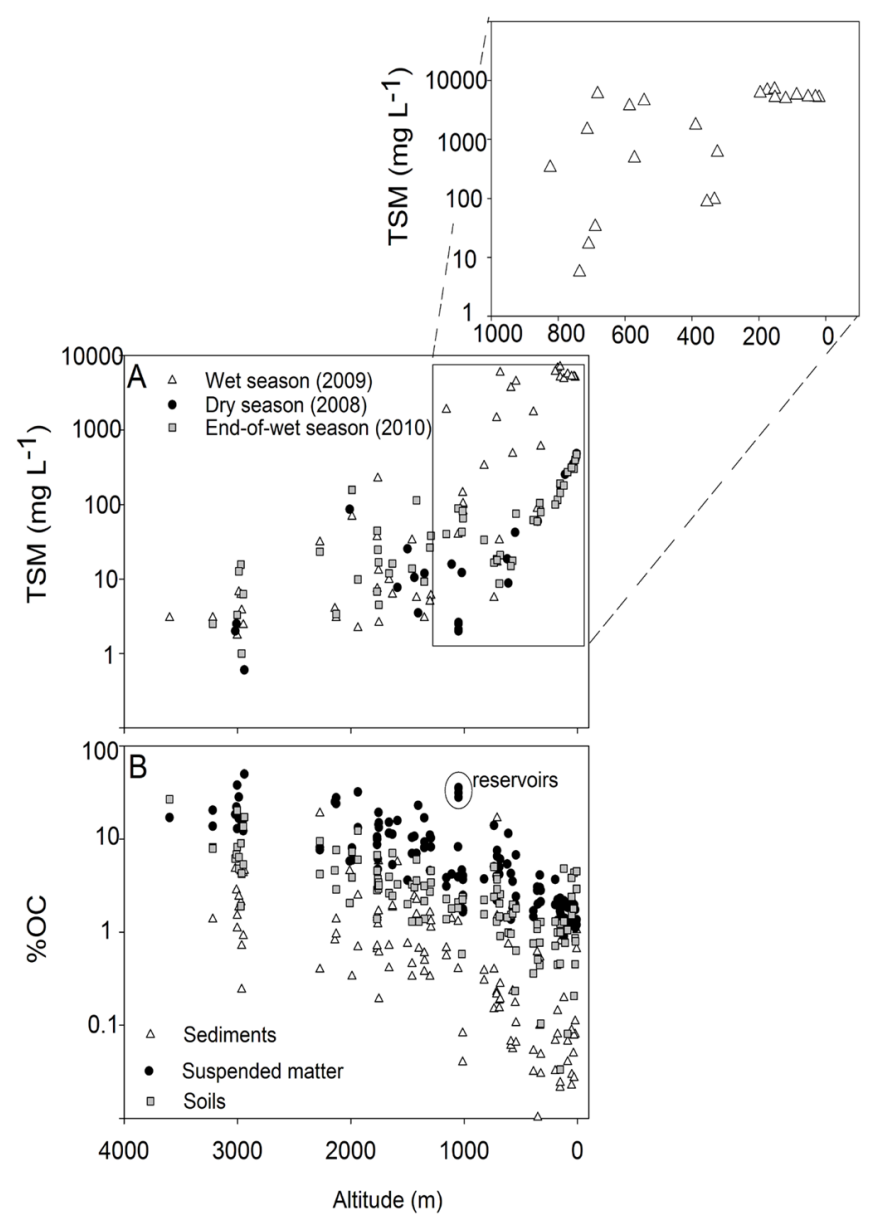

Fig. 3. Altitudinal profiles of (A) total suspended matter concentrations, and (B) \% OC in suspended matter, soils and sediments along Tana River Basin during three sampling seasons. For panel (B), data from the different sampling seasons were combined.

( 0.3 to $\left.5.8 \mathrm{mg}^{-1}\right)$ and end of wet-season $\left(0.4\right.$ to $\left.12.6 \mathrm{mg} \mathrm{l}^{-1}\right)$ (Supplement Table 1). POC concentrations show a similar pattern with altitude as TSM, i.e. a consistent downstream increase during all sampling campaigns (Pearson correlation, $p<0.01$ ).

The organic $\mathrm{C}$ content (\% OC) of the suspended matter ranged from 1.1 to $49.8 \%, 0.9$ to $32.1 \%$ and 1.2 to $37.9 \%$ for dry season, wet season and end of wet season campaigns, respectively (Supplement Table 1), and the organic C content decreased downstream (Fig. 3b). TSM and \% OC showed an inverse relationship during the three seasons (Pearson correlation, $p<0.01$ ). $\mathrm{POC}$ : $\mathrm{PN}$ ratios (weight : weight) were significantly lower $(p<0.05)$ during the wet season $(9.6 \pm 2.5)$ as compared to end of wet season (11.3 \pm 3.0$)$ and dry-season $(10.5 \pm 2.6)$ datasets (Supplement Table 1).

The $\delta^{13} C_{\text {POC }}$ values ranged from -26.5 to $-21.2 \%$, -31.8 to $-19.9 \%$, and -27.1 to $-21.4 \%$ o with means of $-23.8 \pm 1.6 \%,-24.7 \pm 2.8 \%$ and $-24.3 \pm 1.6 \%$ during dry season, wet season and end of wet season campaigns, respec- tively (Supplement Table 1; Fig. 4a). The values for different seasons were not significantly different (paired t-test, $p>$ 0.05 ). Generally, the $\delta^{13} \mathrm{C}_{\mathrm{POC}}$ values increased downstream during all the three sampling campaigns (Pearson correlation, $p<0.01$; Fig. 4a). Overall, the $\delta^{13} \mathrm{C}_{\mathrm{POC}}$ values during the three seasons were not significantly different for headwaters and so were the values for the lower main Tana (paired ttest, $p>0.05$ ). However, values for most sites above $2950 \mathrm{~m}$ in Aberdares and Mt. Kenya headwaters were more ${ }^{13} \mathrm{C}$ enriched. Overall, Mt. Kenya tributaries were the most depleted $(-26.3 \pm 2.0 \%)$, Aberdares and Nyambene Hills intermediate $(-24.6 \pm 1.0$ and $-24.0 \pm 1.8 \%$, respectively) and Tana River mainstream the most enriched $(-22.5 \pm 1.0 \%$ ). POC : Chl $a$ ratios were generally high (75 to 40781 ) with remarkably low values recorded in reservoirs (Supplement Table 1; Fig. 4b).

\subsection{Dissolved organic carbon and $\delta^{13} C_{D O C}$}

Concentrations of DOC during the dry season (0.3 to $2.5 \mathrm{mg}^{-1}$ ) were significantly lower (paired t-test, $p<0.01$ ) compared to wet season $\left(0.2\right.$ to $\left.6.4 \mathrm{mg} \mathrm{l}^{-1}\right)$ and end of wet season (2.1 to $6.9 \mathrm{mg}^{-1}$ ) (Supplement Table 1; Fig. 5a). Overall, DOC values for Aberdares, Mt. Kenya tributaries and Tana River mainstream showed seasonal differences $(p<0.01)$ but values for Nyambene Hills tributaries were similar during the three seasons $(p>0.05)$. DOC concentration increased downstream during wet season (Pearson correlation, $p<0.01$; Fig. 5a).

The $\delta^{13} \mathrm{C}_{\mathrm{DOC}}$ values ranged from -27.7 to $-21.8 \%$, -26.9 to $-21.4 \%$ and $-26.9 \%$ o to $-20.9 \%$, with means of $-23.8 \pm 1.1 \%,-24.4 \pm 1.3 \%$ and $-24.0 \pm 1.1 \%$ for dry season, wet season and end of wet season campaigns, respectively (Supplementy Table 1; Fig. 5b). The values were similar during all the three campaigns (paired t-test, $p>$ $0.05)$. The mean values were $-24.2 \pm 1.0 \%$ o, $-24.6 \pm 1.3 \%$, $-24.2 \pm 1.7 \%$ and $-23.7 \pm 0.9 \%$ for Aberdares (1763 to 3600 m), Mt. Kenya (572 to 2964 m), Nyambene Hills (333 to $736 \mathrm{~m}$ ) tributaries and Tana mainstream (8 to $1054 \mathrm{~m})$, respectively. $\delta^{13} \mathrm{C}_{\mathrm{DOC}}$ and $\delta^{13} \mathrm{C}_{\mathrm{POC}}$ were significantly correlated during the wet season only (Pearson correlation, $r^{2}=0.55 ; p<0.01$; Fig. $\left.6 \mathrm{a}\right)$. The ratio of dissolved to particulate organic C (DOC: POC) ranged from 0.02 to 16.4 for the entire dataset over the three campaigns. The means were $0.95 \pm 0.59,1.52 \pm 2.50$ and $2.26 \pm 2.01$ for dry season, wet season and end of wet season campaigns, respectively. DOC : POC ratios showed a decreasing trend with TSM, and hence generally decreased downstream during all the three seasons (Pearson correlation, $p<0.01$; Fig. 7).

\subsection{Soil and sediment carbon pools}

Data on $\%$ OC of soils and riverine sediments were combined for the three sampling campaigns. The soil \% OC ranged between 0.03 to $20.2 \%$ (Supplement Table 2), with a mean 

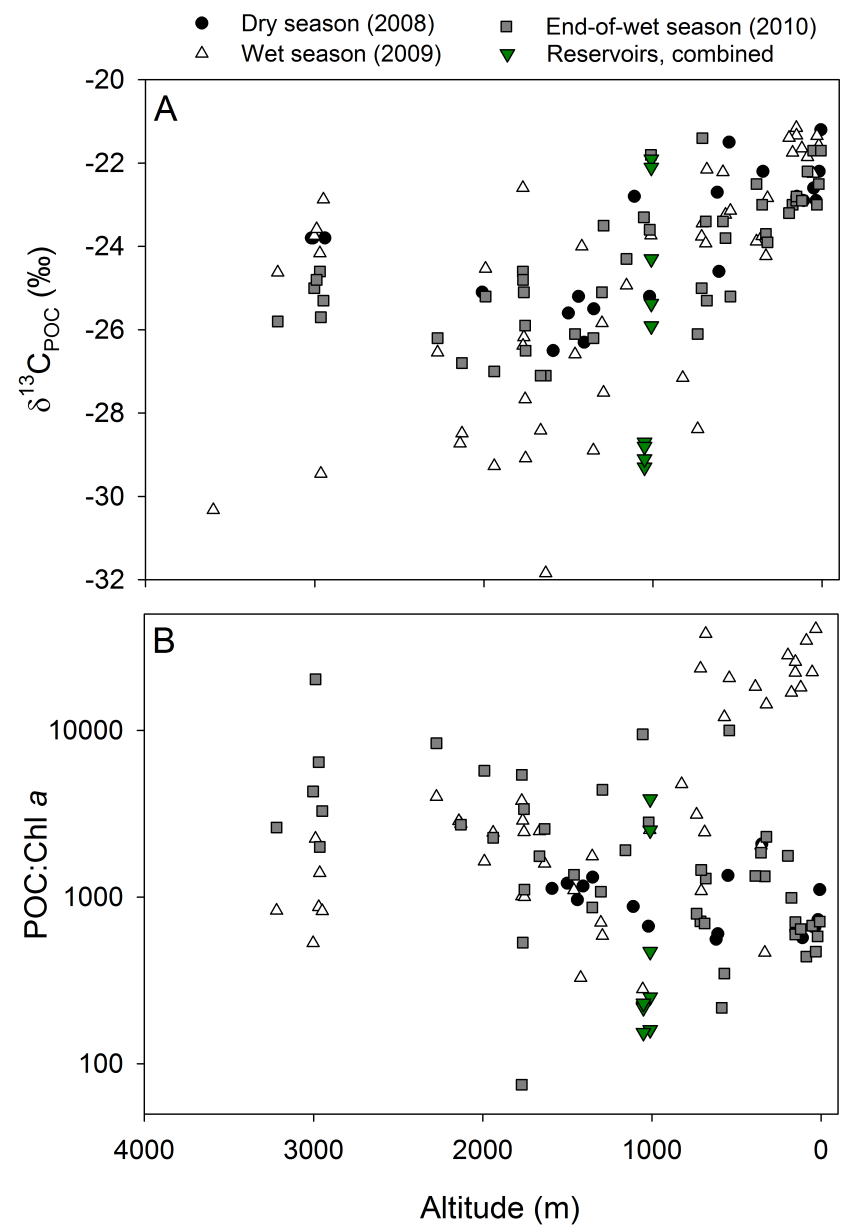

Fig. 4. Altitudinal profile of (A) $\delta^{13} \mathrm{C}_{\mathrm{POC}}$ and (B) POC : Chl $a$ ratios along Tana River Basin during three sampling seasons. Data from the reservoirs are from all sampling campaigns combined and include those from Bouillon et al. (2009).

basin-wide value of $3.5 \pm 3$.9. Similarly, the $\%$ OC of riverine sediment ranged from 0.01 to $5.7 \%$ with a basin-wide mean of $1.3 \pm 2.6$ (Supplement Table 2). Both the soil and sediment $\%$ OC decreased consistently downstream (Pearson correlation, $p<0.01$; Fig. 3b). Soil and sediment values were significantly different (paired t-test, $p<0.05$ ). The $\delta^{13} \mathrm{C}$ values of the soil show a weak positive correlation with altitude (Pearson correlation, $r^{2}=0.23 ; p<0.05$ ), and an overall range between -28.5 and $-13.2 \%$ (Supplement Table 2). The $\delta^{13} \mathrm{C}$ data of the riverine sediment showed a slightly smaller range (between -27.8 and $-16.2 \%$ - Supplement Table 2) and did not show a systematic pattern with altitude (Pearson correlation, $p>0.05$ ).

Overall, \% OC from riverbank soil depth profiles ranged between 0.05 to $1.7 \%$ whereas $\delta^{13} \mathrm{C}$ values ranged between -26.1 and $-11.9 \%$ (Supplement Table 3). The \% OC decreased with depth while $\delta^{13} \mathrm{C}$ values generally increased with depth at Tana Primate and Garsen sites (Pearson correla-
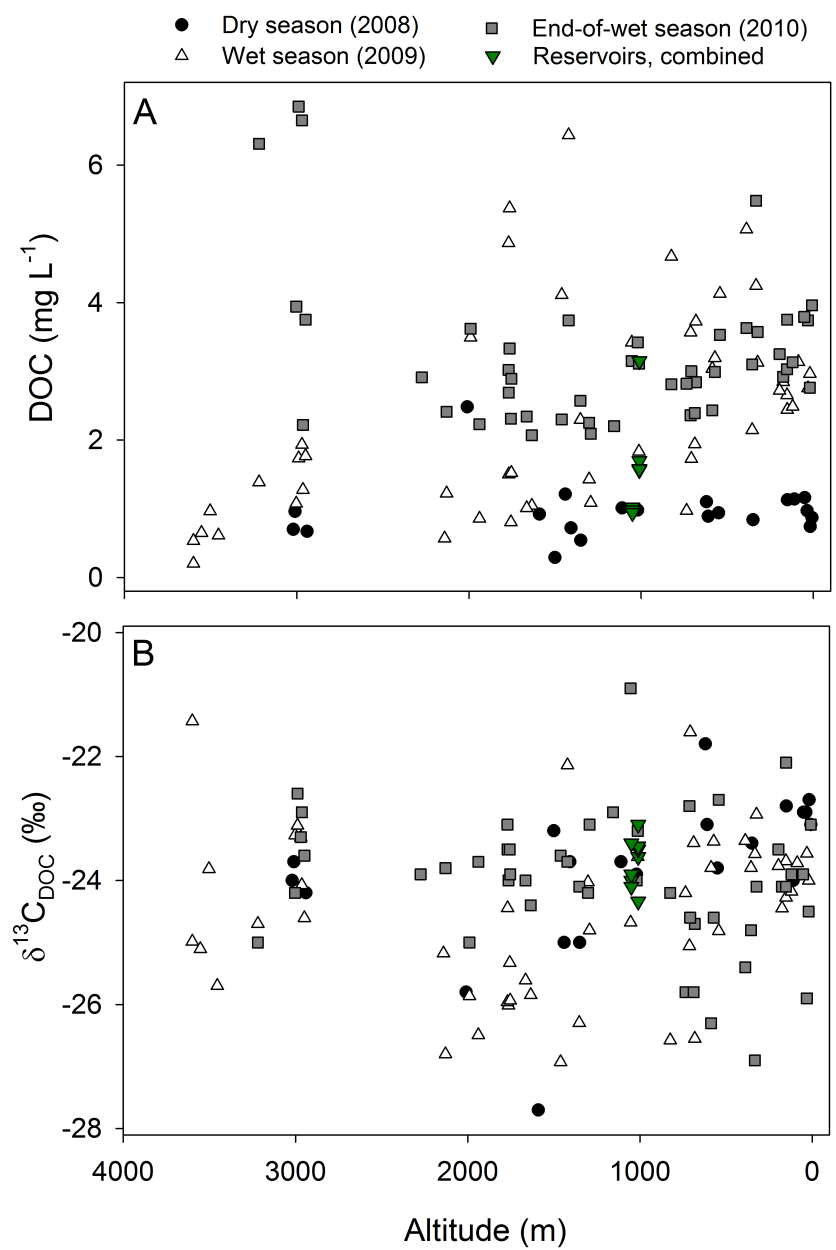

Fig. 5. Altitudinal profile of (A) DOC concentration, and (B) $\delta^{13} \mathrm{C}_{\text {DOC }}$ along Tana River Basin during three sampling seasons.

tion, $p<0.05$ ) but no systematic patterns could be discerned at the Garissa and Hola sites (Pearson correlation, $p>0.05$; Supplement Table 3).

Sediment $\%$ OC on cores from Masinga Reservoir ranged from 1.1 to $1.9 \%$ (Supplement Table 4), and although concentrations differed between the cores, they generally decreased with depth (Fig. 8a); while that of sediments in Kamburu Dam was $1.84 \%$ (Supplement Table 2). The $\delta^{13} \mathrm{C}$ values from Masinga cores ranged between -19.6 and $-15.7 \%$ o (Supplement Table 4), and increased consistently with depth (Fig. 8b) whereas the single sample from Kamburu dam sediment was $-20.7 \%$.

\subsection{Specific surface areas}

Specific SA ranged between 2.4 to $98.2 \mathrm{~m}^{2} \mathrm{~g}^{-1}, 0.9$ to $105 \mathrm{~m}^{2} \mathrm{~g}^{-1}$ and 39.9 to $82.3 \mathrm{~m}^{2} \mathrm{~g}^{-1}$ for soil, riverine sediment and suspended matter, respectively (Supplement Table 5). The SA for soils and riverine sediments decreased consistently downstream (Pearson correlation, $p<0.01$; 

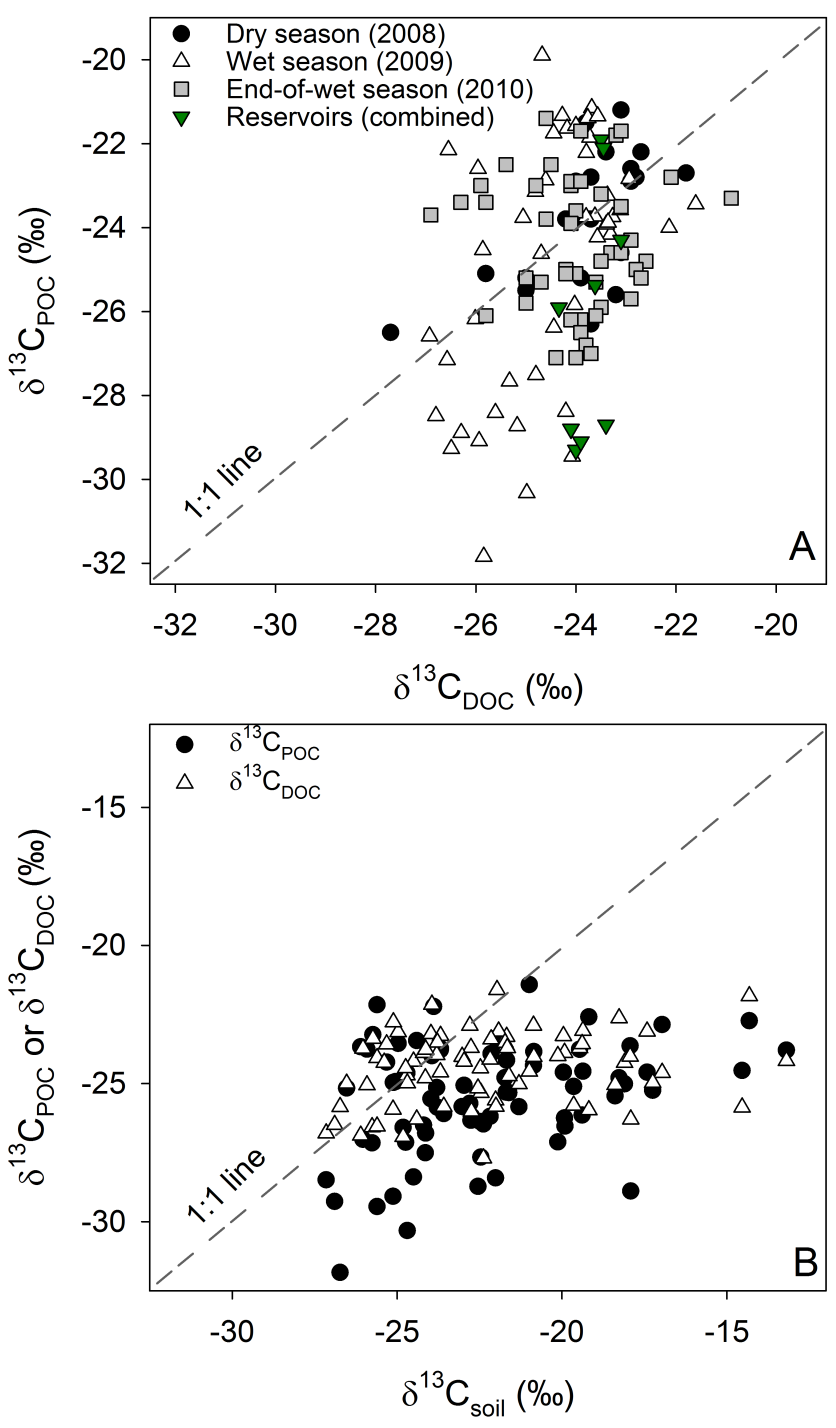

Fig. 6. Plots of (A) $\delta^{13} \mathrm{C}_{\mathrm{POC}}$ vs. $\delta^{13} \mathrm{C}_{\mathrm{DOC}}$ throughout the Tana River Basin, (B) $\delta^{13} \mathrm{C}_{\text {soil vs. }} \delta^{13} \mathrm{C}_{\mathrm{POC}}$ and $\delta^{13} \mathrm{C}_{\mathrm{DOC}}$ for tributaries along Tana River Basin (i.e. mainstream data not included in panel B).

Fig. 9a) while those of suspended matter increased downstream. Riverine sediment \% OC and SA were positively correlated (Pearson correlation, $p<0.01$; Fig. 9b) but soil and suspended matter were not correlated $(p>0.05)$. The SA values from the Masinga (Supplement Table 4) and Kamburu (Supplement Table 5) reservoirs sediments were notably high, and ranged between 59.8 to $93.8 \mathrm{~m}^{2} \mathrm{~g}^{-1}$. The $\mathrm{OC}: \mathrm{SA}$ ratios ranged between 0.1 to $14.6 \mathrm{mg} \mathrm{OC} \mathrm{m}^{-2}, 0.1$ to $7.1 \mathrm{mg} \mathrm{OC} \mathrm{m}^{-2}$ and 0.2 to $0.5 \mathrm{mg} \mathrm{OC} \mathrm{m}^{-2}$ for soil, sediment and suspended matter, respectively (Supplement Table 5). Generally, soil OC:SA ratios were significantly higher than riverine sediments $(p<0.01)$. However, OC: $\mathrm{SA}$ ratios did not show a systematic pattern with altitude. The OC:SA ratios from Masinga and Kamburu dams sediment cores ranged

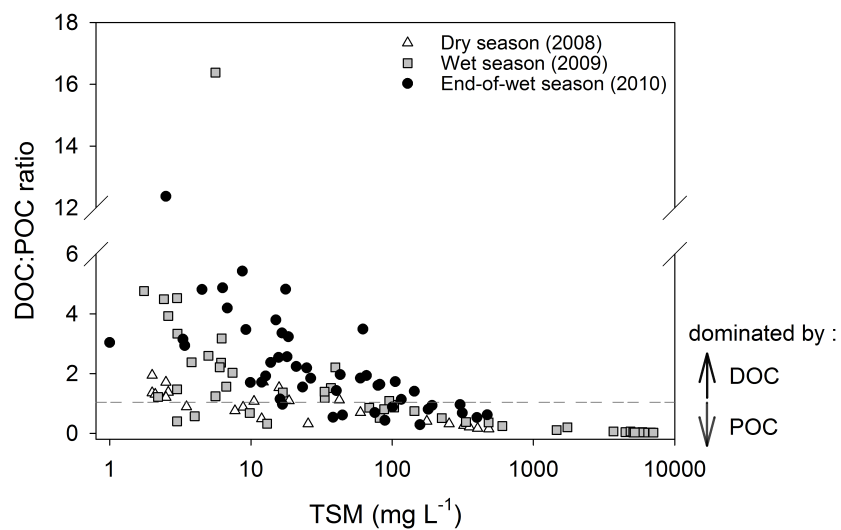

Fig. 7. Relation between DOC: $\mathrm{POC}$ ratio vs. TSM along Tana River Basin, (B) $\% \mathrm{OC}$ vs. $\delta^{13} \mathrm{C}_{\mathrm{OC}}$ for tributaries upstream of Masinga reservoir. Horizontal line in panel (A) indicates a DOC : POC ratio of 1 .

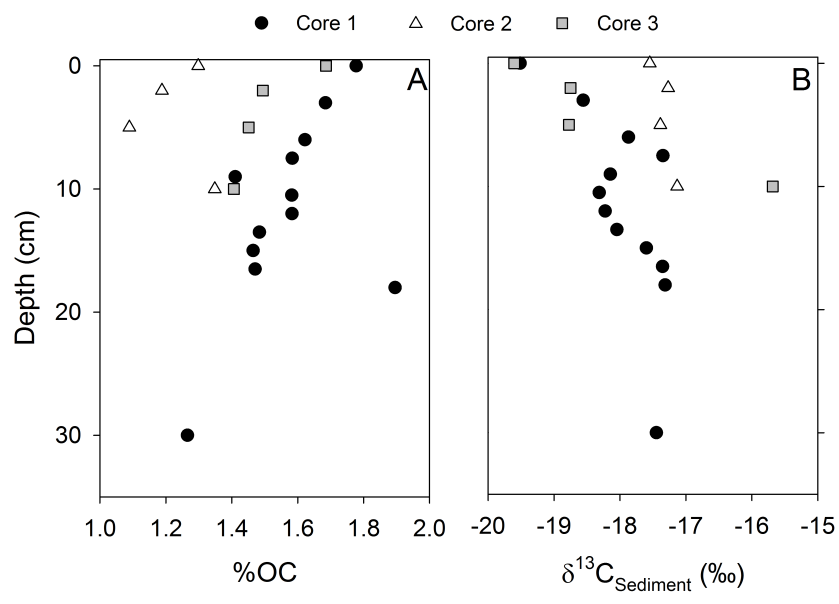

Fig. 8. Plots of (A) sediment core depth vs. sediment \% OC (B) sediment core depth vs. $\delta^{13} \mathrm{C}_{\text {sediment }}$ at Masinga Reservoir.

between 0.16 to $0.25 \mathrm{mg} \mathrm{OC} \mathrm{m}^{-2}$. However, neither SA nor the OC:SA ratio exhibited a systematic pattern with core depth.

\subsection{Activities of radionuclides}

The particulate activity ratios of ${ }^{7} \mathrm{Be} /{ }^{210} \mathrm{~Pb}_{\mathrm{xs}}\left({ }^{7} \mathrm{Be} /{ }^{210} \mathrm{~Pb}_{\mathrm{xs}}\right.$ $\mathrm{AR}$ ) ranged between 0.5 and 2.4 during wet season and increased consistently downstream (Pearson correlation, $p<$ $0.05 ; R^{2}=0.76$; Fig. 10a), while during the end of wet season campaign, values showed greater variability, and ranged between 0.02 and 4.5 (Supplement Table 6; Fig. 10a). The age of suspended sediment ranged from 124 to 244 days and 75 to 478 days during wet and end of wet season, respectively (Fig. 10b). 

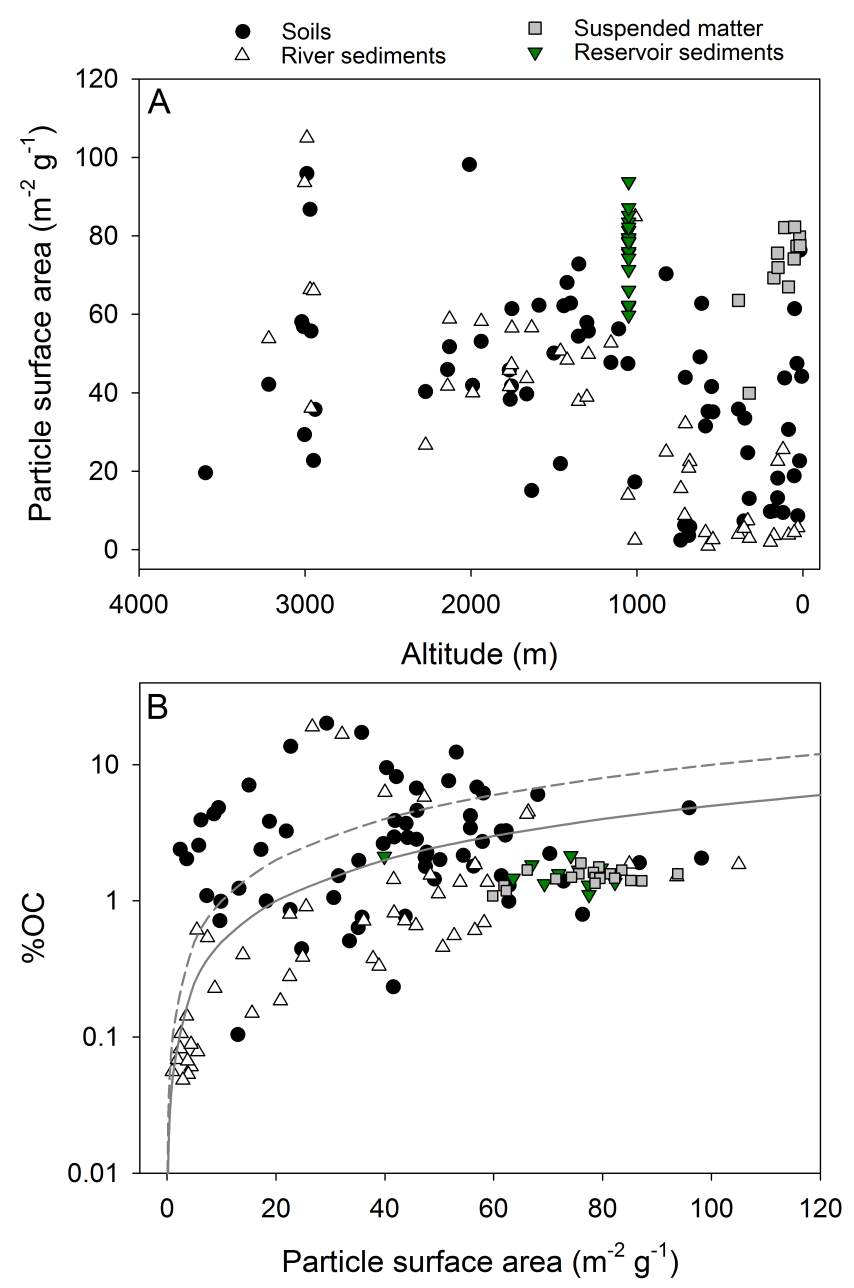

Fig. 9. Profile of (A) altitude vs. SA, (B) SA vs. \% OC of soil, sediment and suspended matter along Tana River Basin during three sampling seasons. Dashed lines bound the monolayer equivalent lines; region of organic carbon to surface area ratios (OC:SA) of $0.5-1.0 \mathrm{mg} \mathrm{OC} \mathrm{m}^{-2} \mathrm{SA}$.

\section{Discussion}

\subsection{Sediment dynamics along the Tana River flow-path}

As expected (Dunne and Ongweny, 1976; Kitheka et al., 2005), TSM concentrations were highest during highflow conditions of the wet season, in particular for the lower main Tana River. TSM profiles during all seasons studied show that, with few exceptions, high-altitude streams have relatively low TSM concentrations. Considering that the Tana River sustains several reservoirs along its channel, a substantial amount of sediment is trapped, with Masinga and Kamburu dam alone estimated to retain $\sim 6.0$ and 3.0 million $\mathrm{t} \mathrm{yr}^{-1}$, respectively (Dunne and Ongweny, 1976; Brown and Schneider, 1998 and references therein). Despite the presence of these reservoirs, high TSM values were recorded beyond the reservoirs in the lower main Tana. The TSM pro- file is much more variable during the wet season, with several minima and maxima along the lower river course (see Fig. 3a, note the log scale on the y-axis). Sediment inputs could be expected from the ephemeral streams (lagas) during flash floods. Monthly sampling conducted by Kitheka et al. (2005) for two years between 2000 to 2003 recorded TSM concentrations in the range of 530 to $1930 \mathrm{mg} \mathrm{l}^{-1}$ at Garsen (see Fig. 1 for location). The maximum of this range is much lower than the value we recorded during our wet season campaign at the same site $\left(5098 \mathrm{mg} \mathrm{l}^{-1}\right)$. Compared to many other African river systems (e.g. Martins, 1983; Lesack et al., 1984; Seyler et al., 1995; Bird et al., 1998; Coynel et al., 2005; 1.7 to $135 \mathrm{mg} \mathrm{l}^{-1}$ ), the TSM concentrations encountered in the lower main Tana during the wet season were exceptionally high.

In the dry and end of wet season, TSM concentration data are lower than in the wet season, but still high at Masinga bridge located $\sim 2 \mathrm{~km}$ downstream of Masinga reservoir compared to the headwaters (Supplement Table 1). Moreover, there is a very conspicuous and strong increase in TSM along the lower main Tana (Fig. 3a) where the river flows through semi-arid plains for $\sim 700 \mathrm{~km}$, and where no tributaries discharge in the dry season. Based on data from the dry season sampling in 2008, Bouillon et al. (2009) suggested that resuspension of internally stored riverbed sediments could offer an explanation for the gradual downstream increase in TSM observed during low flow conditions. An alternative interpretation for this downstream increase in TSM below the reservoirs is that the lower Tana River is in a non-equilibrium state with respect to sediment transport. Past studies have documented similar impacts of upstream damming to downstream river networks (Scodanibbio and Mañez, 2005), such as river channel incision, associated riverbank erosion and downstream sedimentation (Rosgen, 1997). In the case of the Tana River, Maingi and Marsh (2002) reported that following the construction of Masinga dam, river meandering rates have decreased and the river channel of the lower Tana has deepened. Our observations of strongly increasing TSM concentrations during different stages of the hydrograph thus suggest that much of the sediment generated in the lower section of the Tana River, at least during periods of lower discharge, is derived from the collapse of incised and unstable riverbanks, whereas during the wet season, high TSM concentration are likely contributed by both riverbank erosion and surface erosion.

The contribution of bank sediments in explaining the increasing TSM load along the lower Tana River appears to be consistent with OC data from riverbank soils. The high TSM loads coincide with lower \% POC values and higher $\delta^{13} \mathrm{C}_{\mathrm{POC}}$ signatures, and a comparison with bank soil data illustrates that these could represent an end-member consistent with observations on the riverine POC (Fig. 11b).

Variations in ${ }^{7} \mathrm{Be} /{ }^{210} \mathrm{~Pb}_{\mathrm{xs}}$ ratios form an important tool for tracing suspended particles along the river continuum (Matisoff et al., 2005; Saari et al., 2010). In the context of 
Wet season

$\triangle$ End of wet season
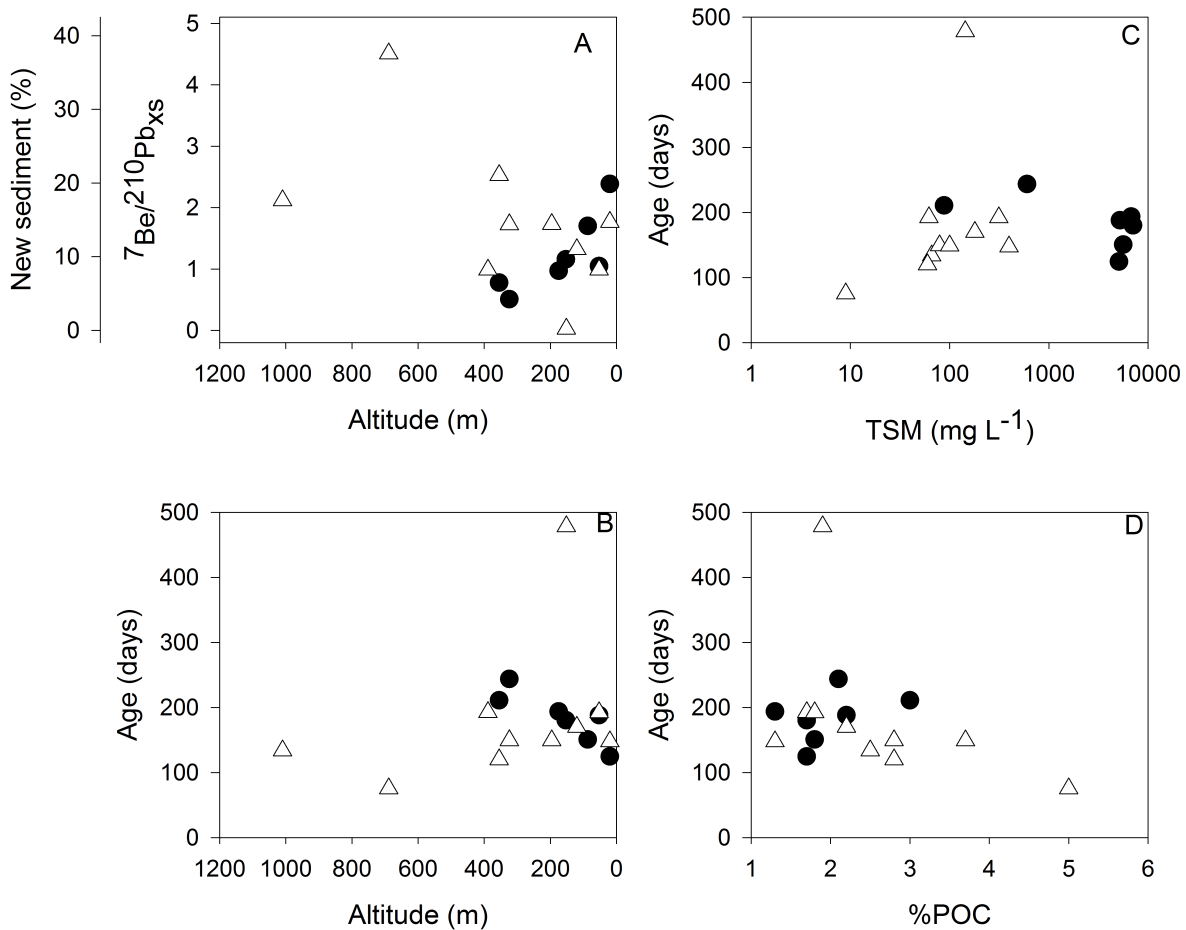

Fig. 10. Overview of results of ${ }^{7} \mathrm{Be} /{ }^{210} \mathrm{~Pb}_{\mathrm{xs}}$ measurements on suspended sediment samples in the Tana River during wet season and end of wet season: (A) altitudinal profile of ${ }^{7} \mathrm{Be} /{ }^{210} \mathrm{~Pb}_{\mathrm{xs}}$ ratios, and the estimated \% new sediment, (B) altitudinal profile of the estimated suspended matter age, $(\mathbf{C})$ relationship between suspended matter age and TSM concentrations, and (D) relationship between suspended matter age and $\%$ POC.

identifying the sources of sediments in the lower Tana River, these data allow us to make an analysis of the relative importance of surface erosion (material with high ${ }^{7} \mathrm{Be} /{ }^{210} \mathrm{~Pb}_{\mathrm{xs}}$ ratios) versus riverbed resuspension or riverbank collapse (material with low ${ }^{7} \mathrm{Be} /{ }^{210} \mathrm{~Pb}_{\mathrm{xs}}$ ratios, Whiting et al., 2005). Although the number of samples is limited, our data show a number of interesting patterns which allow to put some first order constraints on the origin of riverine suspended matter (Fig. 10). First, along an altitudinal gradient, differences between seasons are not very pronounced (Fig. 10a, b) since variations along the riverine continuum within a sampling season are quite strong. Secondly, when plotting the average of suspended sediments versus TSM concentrations, there appears to be a gradual increase in age with increasing TSM during dryer conditions, with one site showing exceptionally high sediment age (with an estimated contribution of new sediment of $0 \%$, Fig. 10c). This suggests that during low flow conditions, the increasing TSM concentrations downstream are caused by inputs of older sediments, with bank erosion and/or resuspended sediments being the main candidate sources. A contribution by riverbank collapse would contribute ${ }^{7} \mathrm{Be}$-deficient sediment to the river suspended matter load (Whiting et al., 2005), since it brings in deeper soil layers with an older radionuclide signature. Internal resuspension of river sediments would have a similar effect on ${ }^{7} \mathrm{Be} /{ }^{210} \mathrm{~Pb}_{\mathrm{xs}}$ ratios, but as noted above, this mechanism less likely accounts for the large downstream increase in TSM observed during dry conditions. During the wet season, however, the much higher TSM concentrations do not follow this trend, as they show sediment ages in the same range as those observed at much lower TSM concentrations during dryer conditions (Fig. 10c). This suggests a contribution of recently eroded material during the wet season, as also indicated by the decreasing sediment age downstream (Fig. 10b). Despite the evidence for recently eroded sediment, the estimated \% contribution of new sediment is overall relatively low $(8-20 \%$ in the lower Tana River during the wet season, Fig. 10a). Finally, it can be noticed that when pooling the different data, the suspended matter samples representing more recently eroded material correspond to those with higher \% POC values (Fig. 10d), consistent with topsoil erosion which is expected to have a higher organic matter content than deeper soil layers or riverbanks. 


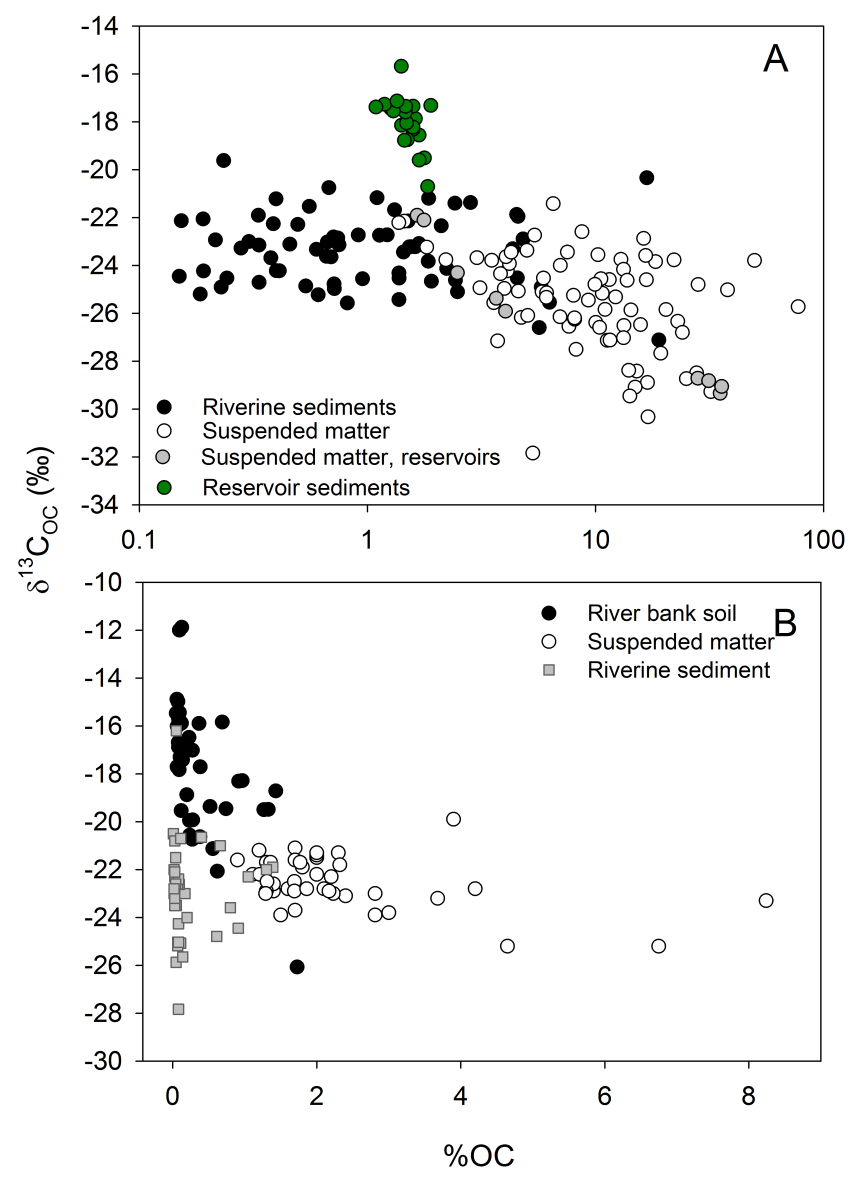

Fig. 11. Comparison between (A) $\%$ OC vs. $\delta^{13} \mathrm{C}_{\mathrm{OC}}$ for tributaries upstream of Masinga reservoir, (B) $\% \mathrm{OC}$ vs. $\delta^{13} \mathrm{C}$ for the lower Tana River.

\subsection{Longitudinal changes in riverine organic carbon cycling}

The high \% POC and POC: Chl $a$ ratios in the upstream reaches (Supplement Table 1) suggest that POC is predominantly terrestrial, and the low $\delta^{13} \mathrm{C}_{\mathrm{POC}}$ values point towards C3 plant species, which are dominant in the high altitude headwater catchments. The $\delta^{13} \mathrm{C}_{\mathrm{POC}}$ values increase downstream in contrast to patterns observed in the Amazon basin (Cai et al., 1988; Townsend-Small et al., 2005; Aufdenkampe et al., 2007), although a similar pattern has been reported in a tropical river system in Cameroon (Bird et al., 1994b). Such a downstream increase in $\delta^{13} \mathrm{C}_{\mathrm{POC}}$ could result from a combination of two processes: (i) altitudinal differences in the $\delta^{13} \mathrm{C}$ signature of $\mathrm{C} 3$ vegetation, and/or (ii) a shift towards a higher contribution of $\mathrm{C} 4$ vegetation at lower altitudes. Regarding the first mechanism, $\delta^{13} \mathrm{C}$ values of $\mathrm{C} 3$ plants have been reported to increase with decreasing mean annual precipitation (e.g. Kohn, 2010). The rainfall pattern in Tana River basin decreases from $2200 \mathrm{~mm} \mathrm{yr}^{-1}$ at high altitudes to $450 \mathrm{~mm} \mathrm{yr}^{-1}$ in lower and drier Tana catchment
(Brown and Schneider, 1998). Employing these precipitation data together with the empirical relationship between altitude, precipitation and $\delta^{13} \mathrm{C}$ of $\mathrm{C} 3$ vegetation established by Kohn (2010), the average C3 vegetation is expected to have average signatures of -28.7 and $-26.5 \%$ ofor the highest and lowest altitudes, respectively, i.e. a shift of $+2.2 \%$ o. This shift is much smaller than the observed shift of $\sim 7 \%$ in our dataset, (Fig. 4a). This indicates that the downstream increase in $\delta^{13} \mathrm{C}$ values is to a large extent due to increased contributions from $\mathrm{C} 4$ vegetation or $\mathrm{C} 4$-dominated soil organic matter. One notable exception to this elevational pattern is the much higher than expected $\mathrm{C} 4$ contribution at some of the high altitude sites (Aberdares, Mt. Kenya), where POC show distinctly higher $\delta^{13} \mathrm{C}$ signatures (Fig. 4a). This observed $\mathrm{C} 4$ contribution is explained by the frequent occurrence of A. amethystinus, a tussock-forming $\mathrm{C} 4$ grass species in high altitude sites ( $>3000 \mathrm{~m}$, see Tieszen et al., 1979; Wooller et al., 2001), for which our own $\delta^{13} \mathrm{C}$ measurements range between -13.6 and $-12.1 \%$.

The downstream increase in $\mathrm{C} 4$ vegetation as reflected in $\delta^{13} \mathrm{C}_{\mathrm{POC}}$ values is related to an increasing aridity and the associated vegetation gradient, where forested ecosystems at high altitudes gradually shift towards savannah dominated ecosystems along the lower main Tana. Based on a simple mixing model, and using end-member values for $\mathrm{C} 4$ and $\mathrm{C} 3$ vegetation of -12.1 and $-27.6 \%$ respectively, the estimated C3 contribution in the POC pool in the lower main Tana is surprisingly high (63\%), despite the open savannah vegetation in the lower altitude Tana basin probably due to contribution from riverine forest. Past studies from other tropical rivers suggest minimal contribution of POC from algal sources in fluvial systems (Bird et al., 1994a, b). The $\delta^{13} \mathrm{C}$ signatures for POC at Masinga (Bouillon et al., 2009) and Kamburu dams showed depleted $\delta^{13} \mathrm{C}$ values, low POC : Chl $a$ ratios, high \% POC and low POC : PN ratios, thus reflecting POC contributions from algal sources (Supplement Table 1; Fig. 4a, b). This effect was particularly pronounced during dry season campaign (Bouillon et al., 2009). Yet, in our riverine samples, there is a negligible contribution of phytoplankton to the POC pool as confirmed by the high POC : Chl $a$ ratios.

The $\delta^{13} \mathrm{C}$ values for Masinga dam sediment cores were surprisingly high $(-19.5$ to $-17.3 \%$ ) and inconsistent with the values measured in tributaries feeding into the Masinga reservoir (Fig. 11b). These signatures similarly do not match the phytoplankton in the reservoir (grey symbols in Fig. 11b), suggesting that selective retention of particles associated with the $\mathrm{C} 4$ fraction or/and preferential mineralization of isotopically light POM could be responsible for these unexpected $\delta^{13} \mathrm{C}$ signatures. Indeed, there appear to be more ${ }^{13} \mathrm{C}$ depleted signatures in the surface layers, increasing downcore coinciding with a loss of OC (Fig. 9b). Since phytoplankton $\delta^{13} \mathrm{C}$ signatures in this reservoir is found to be quite ${ }^{13} \mathrm{C}$-depleted, the downcore variations would be consistent with a preferential loss of more labile in situ production. 
Nevertheless, the $\delta^{13} \mathrm{C}$ values found in deeper layers still reflect a $\mathrm{C} 4$ contribution which is much higher than would be expected based on $\delta^{13} \mathrm{C}_{\mathrm{POC}}$ signatures in the inflowing rivers (Fig. 11b).

Preferential mineralisation of the $\mathrm{C} 3$ component of riverine inputs would conflict with the hypothesis proposed by Wynn and Bird (2007) that C4 derived organic matter decomposes faster than $\mathrm{C} 3$-derived material. One possible mechanism to reconcile these results is related to particle sorting effects, whereby the $\mathrm{C} 4$ component is well protected on the finer particles and that our samples, collected towards the outflow of the reservoir, represent this finer fraction (which would be consistent with the high SA values, Fig. 8a). A first-order estimate of post-depositional $\mathrm{C}$ losses can be obtained by comparing the \% OC data between the upper and lower layers of the deepest sediment core. This way, we estimate a $\sim 30 \%$ OC loss thus suggesting a relatively high burial efficiency of organic $\mathrm{C}(\sim 70 \%)$ in the Masinga reservoir. The burial efficiency of $\mathrm{OC}$ in our study is significantly higher than the $\sim 40 \%$ reported in other temperate and tropical lakes (Sobek et al., 2009; Kunz et al., 2011), but it should be stressed that our estimate is derived from a limited number of data. Nevertheless, even this coarse estimate underscores the significant role reservoirs play as sinks in global $\mathrm{C}$ cycle (Cole et al., 2007; Battin et al., 2008; Tranvik et al., 2009). The surface area (SA) for suspended matter along lower main Tana $\left(60-80 \mathrm{~m}^{2} \mathrm{~g}^{-1}\right)$ were within the same range as those reported by Bouillon et al. (2009) but are much higher than those reported for coastal sediments, estuaries and rivers $\left(<50 \mathrm{~m}^{2} \mathrm{~g}^{-1}\right)$ (Mayer, 1994; Keil et al., 1997; Aufdenkampe et al., 2007). Compared to the TSM, the riverine sediment showed a much larger range in SA due to the sandy and muddy deposits in the riverbed. As expected (Mayer, 1994; Keil et al., 1997), riverine sediment \% OC showed a positive correlation with SA (Fig. 8b), a strong indication of protective organic matter adsorption to mineral surface areas. For coarser, sandy sediments (low SA values), \% OC were generally higher than expected for the "monolayer equivalent" (Mayer, 1994), whereas the opposite was true for more clayrich riverine sediments (higher SA). This would be consistent with a significant fraction of non-bound particulate matter in coarser sediments, while most of the particulate $\mathrm{C}$ in finegrained sediments is more strongly bound to clay minerals. In contrast, soil \% OC did not show significant relationship with corresponding SA (Fig. 8b), and the majority of soil samples had \% OC values above the monolayer equivalence lines, which is consistent with a contribution from non-bound plant-derived organic matter. The OC:SA ratios for riverine sediments were consistently lower than those of soils with similar SA values, suggesting that riverine OC particles have been subjected to extensive degradation losses. All reservoir sediments and suspended matter samples showed high SA values of $>60 \mathrm{~m}^{2} \mathrm{~g}^{-1}$, and organic $\mathrm{C}$ loadings were always below the monolayer equivalent zone. The observed range of OC:SA values in these suspended matter and reservoir sediment samples $\left(0.14-0.53\right.$ and $0.16-0.25 \mathrm{mg} \mathrm{OC}^{-2}$, respectively) are markedly lower than the range previously observed in other large river systems such as the Amazon, Fly, Columbia, and Hung He (typically between 0.25 and 1 ; see Keil et al., 1997), and fall more in the range of values found in coastal or marine sediments (Aufdenkampe et al., 2007). These low OC: SA values thus suggest a very stable organic $\mathrm{C}$ pool which has undergone extensive degradation of the more labile fractions during erosional and riverine transport and retention cycles.

The relationship between \% POC and TSM followed an inverse relationship as reported for other world rivers (Meybeck, 1982). Two different hypotheses have been proposed to explain this relationship (Thurman, 1985; Ludwig et al., 1996). First, decreasing \% POC in suspended matter with increasing TSM concentrations could reflect the variable contribution of the autochthonous $\mathrm{C}$ produced by riverine phytoplankton. Secondly, this pattern may reflect mixing between more organic-rich surface soil runoff and/or direct litter contributions, and deeper soil-derived sediments with reduced organic $\mathrm{C}$ loading. In our study, the high POC: $\mathrm{Chl} a$ ratios (Fig. 4b) strongly favour the second hypothesis. Only for the reservoirs (Kamburu and Masinga) do our data suggest that the elevated \% POC is explained by in-situ phytoplankton production. The elevated \% POC recorded in headwater tributaries corresponds with high POC: PN ratios (Supplement Table 1), indicating OC is majorly derived from allochthonous fresh plant materials, while low \% POC values recorded in lower main Tana, particularly during wet season campaign, are due to dilution by soil mineral particles (from mechanical erosion associated with surface runoff during flash floods during the wet season and bank instability during dry season). During wet season sampling, high amount of terrigeneous and lithological materials originating from soil and/or bank erosion, characterized by low organic $\mathrm{C}$ content is a dominant characteristic. The \% POC relationship from our data fits well with an empirical model based on Ludwig et al. (1996) data in the lower TSM range (up to $\sim 1000 \mathrm{mg}^{-1}$ ), but $\%$ OC values are markedly higher than global averages in the higher TSM range $\left(>1000 \mathrm{mg} \mathrm{l}^{-1}\right)$. In addition, \% POC was generally higher than soil \% OC, particularly in higher altitude sites due to additional contributions from the riparian vegetation as direct litter inputs or topsoil detritus.

DOC concentrations in the present study (0.2 to $6.9 \mathrm{mgl}^{-1}$ ) are relatively low compared to those reported for other African rivers (range 0.6 to $51.2 \mathrm{mgl}^{-1}$; Martins, 1983; Seyler et al., 1995; Coynel et al., 2005; Brunet et al., 2009; Spencer et al., 2010), but consistent with average values for rivers crossing semi-arid climates as reported by Spitzy and Leenheer (1991). The altitudinal profiles show contrasting patterns during different seasons: for the dry season, concentrations were consistently low throughout the basin (Bouillon et al., 2009), increased downstream during the wet season (Fig. 5a), though highly variable in lower 
altitude $(<2000 \mathrm{~m})$, or showed consistently higher values in the high-elevation sites (end of wet season, Fig. 5a) in Aberdare and Mt. Kenya headwaters, which may be attributed to presence of peatlands and swamps. DOC in high mountain streams are typically much lower than those of other natural waters (Meybeck, 1982; Hedges et al., 2000). However, most of these studies were conducted at higher latitudes where organic-rich peat soils do not occur (TownsendSmall et al., 2005). The generally higher DOC concentrations during the wet and end of wet season would be consistent with a terrestrial-derived origin of DOC, which is also most likely given the minimal contribution of phytoplankton to the POC pool. The downstream increase in DOC concentrations during wet season may be associated with efficient soil organic matter degradation in hotter lower Tana. DOC: POC ratios were relatively low and ranged from 0.02 in the lower reaches of Tana River main channel to 5.5 in the headwaters. DOC typically dominated in the tributaries $(59 \pm 21 \%)$ while POC dominated in the main Tana River (DOC contribution of $34 \pm 23 \%$ ), which is typical for highly erosive and turbid systems and in line with the general trend of lower DOC: POC ratios with increasing TSM (Meybeck, 1982; Ittekkot and Laane, 1991; Middelburg and Herman, 2007; Ralison et al., 2008; Bouillon et al., 2009). The global average contribution of DOC to the total riverine OC pool is highly variable, ranging between 10 and $90 \%$ (Meybeck, 1982) but recent estimates put global mean DOC contribution at $73 \pm 21 \%$, and $61 \pm 30 \%$ for tropical systems (Alvarez-Cobelas et al., 2010). Contrary to the downstream trend observed in $\delta^{13} \mathrm{C}_{\mathrm{POC}}$ values (Fig. $4 \mathrm{a}$ ), $\delta^{13} \mathrm{C}$ signatures of DOC were generally stable (Fig. 5b). The weak correlation between $\delta^{13} \mathrm{C}_{\mathrm{DOC}}$ and $\delta^{13} \mathrm{C}_{\mathrm{POC}}$ (Fig. 6a) suggests that the exchange of $\mathrm{C}$ between POC and DOC pools (through adsorption and desorption reactions, sensu Middelburg and Herman, 2007) is limited.

\subsection{Links between terrestrial and aquatic carbon pools}

Soil \% OC showed a marked altitudinal gradient, with high values in high altitude sites and consistently decreased to low values in sites along the lower Tana River (Fig. 3b). This altitudinal gradient in soil $\mathrm{OC}$ is in accordance with previous and more large-scale datasets on soil OC stocks in Kenya (Batjes, 1996, 2004), and is also observed in other large-scale studies such as in the Amazon basin (e.g. Townsend-Small et al., 2005; Aufdenkampe et al., 2007). A similar gradient was observed in riverine sediment \% OC (Fig. 3b). Such gradients are typically explained by the associated temperature gradient, which leads to less efficient soil organic matter degradation in colder, high-altitude regions (Couteaux et al., 2002; Finlay and Kendall, 2007). As expected (e.g. TownsendSmall et al., 2005), both soil and sediment POC/PN ratios showed an altitudinal gradient, although more pronounced in sediments ( $R^{2}=0.25$ and 0.37 , respectively). The stable isotope composition of soil organic matter in principle reflects the isotope signatures of the vegetation. Thus, soil organic matter $\delta^{13} \mathrm{C}$ values of about $-27 \%$ and $-13 \%$ are expected in areas dominated by $\mathrm{C} 3$ and $\mathrm{C} 4$ plants, respectively (Finlay and Kendall, 2007; Kendall et al., 2001). Although $\delta^{13} \mathrm{C}_{\text {soil }}$ values in the present study do not show systematic patterns with altitude, the values exhibited the full range of $\mathrm{C} 3$ to C4 signatures ( -28.5 to $-13.2 \%$ ) consistent with the variable vegetation patterns within the catchment. The distribution of C 3 and C4 grasses in Kenya has been documented by Tieszen et al. (1979), and they found a clear altitudinal shift of a complete $\mathrm{C} 4$-dominance below $2000 \mathrm{~m}$ to a dominance of $\mathrm{C} 3$ grass species above $3000 \mathrm{~m}$. The $\delta^{13} \mathrm{C}_{\text {sediment }}$ values $(-27.8$ to $-16.2 \%$ ) show a more narrow range of values with less variability than surface soils, considering sediments integrate soil inputs from larger areas and so are more mixed than spot samples in soils. This concurs with data from Bird et al. (1994b) that $\delta^{13} \mathrm{C}_{\text {sediment }}$ values are controlled and/or reflective of the dominant vegetation type present in the river catchment, among other factors such as altitude. It should be stressed that estimates of $\mathrm{C} 3$ and $\mathrm{C} 4$ contributions using soil $\delta^{13} \mathrm{C}$ data refer to $\mathrm{C}$ inputs from these two vegetation types, and do not necessarily reflect their relative standing biomass due to potential differences in their relative productivity and degradability of litter. Gillson et al. (2004), for example, demonstrated that soil $\delta^{13} \mathrm{C}$ data in Kenyan mixed C3-C4 savannas significantly underestimated local C3 plant biomass.

The relationship between $\delta^{13} \mathrm{C}_{\text {soil }}$ values and $\delta^{13} \mathrm{C}_{\mathrm{DOC}}$ and $\delta^{13} \mathrm{C}_{\mathrm{POC}}$ values for tributaries (Fig. $6 \mathrm{~b}$ ) shows that DOC and $\mathrm{POC}$ in the aquatic system usually have a stronger $\mathrm{C} 3$ contribution than soils in the subcatchments (with the obvious caveat that our soil samples are not necessarily representative of the entire subcatchment). Organic matter in some of the tributaries also appears to be partially derived from direct litter inputs, given the higher \% OC than observed in surface soils.

\section{Conclusions}

Generally, suspended matter and POC delivery in Tana River was highest during high-flow conditions, with the majority of the suspended load being generated in the lower section of the Tana River. We propose that riverbank erosion, coupled with sediment pulses from ephemeral streams form the main sources of these high TSM loads. Thus, the cascade of reservoirs on the Tana River at mid-altitude appear to be very efficient traps for suspended material from highaltitude regions, but also result in a disequilibrium in the lower course of the river, with increased sediment mobilisation downstream. The $\delta^{13} \mathrm{C}$ values constrained from bulk $\mathrm{C}$ organic measurements show that $\mathrm{C} 3$ derived organic matter dominates the riverine DOC and POC pools, with important C4 contributions mainly in the high-altitude regions and in the lower Tana. The generally high POC : Chl $a$ ratios suggest 
there is a negligible contribution from in-stream phytoplankton production except in Kamburu and Masinga reservoirs. The $\delta^{13} \mathrm{C}$ values from sediments in Masinga and Kamburu reservoirs do not reflect phytoplankton production but rather selective retention of the $\mathrm{C} 4$ fraction of the organic matter a rather unique observation considering $\mathrm{C} 4$ organic matter is normally preferentially mineralized over $\mathrm{C} 3$. Despite limited data, ${ }^{7} \mathrm{Be} /{ }^{210} \mathrm{~Pb}_{\mathrm{xs}}$ measurements point towards a combination of older sediment sources (bank erosion) and surface erosion as significant sources of riverine suspended matter, the latter particularly during high flow periods.

\section{Supplementary material related to this article is available online at: http://www.biogeosciences.net/9/ 2905/2012/bg-9-2905-2012-supplement.pdf.}

Acknowledgements. Funding for this work was provided by the Research Foundation Flanders (FWO-Vlaanderen, project G.0651.09 and travel grants to F. T., K. v. D. M., and S. B), and the European Research Council (ERC-StG 240002,AFRIVAL, http://ees.kuleuven.be/project/afrival/). We thank Pieter van Rijswijk (NIOZ), Peter van Breugel (NIOZ), Michael Korntheuer (VUB) and Zita Kelemen (KULeuven) for technical and laboratory assistance, Kenya Wildlife Service for faciliting our fieldwork, Olivier Hamerlynck and Stéphanie Duvail for useful discussions and information on the Tana, and WRMA (Water Resource Management Authority) for making the discharge data from Garissa available. AVB is a research associate with the Fonds National de la Recherche Scientifique (FNRS, Belgium). We thank two anonymous referees whose comments and suggestions significantly improved this manuscript.

Edited by: X. Wang

\section{References}

Albéric, P.: Liquid chromatography/mass spectrometry stable isotope analysis of dissolved organic carbon in stream and soil waters, Rapid. Commun. Mass Sp., 25, 3012-3018, 2011.

Alvarez-Cobelas, M., Angeler, D. G., Sánchez-Carrillo, S., and Almendros, G.: A worldwide view of organic carbon export from catchments, Biogeochemistry, 107, 275-294, 2010.

Aufdenkampe, A. K., Mayorga, E., Hedges, J. I., Llerena, C., Quay, P. D., Gudeman, J., Krusche, A. V., and Richey, J. E.: Organic matter in the Peruvian headwaters of the Amazon: compositional evolution from the Andes to the lowland Amazon mainstem, Org. Geochem., 38, 337-364, 2007.

Aufdenkampe, K. A., Mayorga, E., Raymond, A. P., Melack, M. J., Doney, C. S., Alin, R. S., Aalto, E. R., and Yoo, K.: Riverine coupling of biogeochemical cycles between land, oceans, and atmosphere, Front. Ecol. Environ., 9, 53-60, 2011.

Batjes, N. H.: Total carbon and nitrogen in the soils of the world, Eur. J. Soil Sci., 47, 151-163, 1996.
Batjes, N. H.: Soil carbon stocks and projected changes according to land use and management: a case study for Kenya, Soil Use Manage., 20, 350-356, 2004.

Battin, T. J., Kaplan, L. A., Findlay, S., Hopkinson, C. S., Marti, E., Packman, A. I., Newbold, J. D., and Sabater, F.: Biophysical controls on organic carbon fluxes in fluvial networks, Nat. Geosci., 1, 95-100, 2008.

Bird, M. I., Haberle, S. G., and Chivas, A. R.: Effect of altitude on the carbon-isotope composition of forest and grasslands soils from Papua New Guinea, Global Biogeochem. Cy., 8, 13-22, 1994a.

Bird, M. I., Giresse, P., and Chivas, A. R.: Effect of forest and savanna vegetation on the carbon isotope composition of sediments from the Sanaga River, Cameroon, Limnol. Oceanogr., 39, 18451854, 1994b.

Bird, M. I., Giresse, P., and Ngos, S.: A seasonal cycle in the carbon-isotope composition of organic carbon in the Sanaga River, Cameroon, Limnol. Oceanogr., 43, 143-146, 1998.

Bonniwell, E. C., Matisoff, G., and Whiting, P. J.: Fine sediment residence times in rivers determined using fallout radionuclides $\left({ }^{7} \mathrm{Be},{ }^{137} \mathrm{Cs},{ }^{210} \mathrm{~Pb}\right)$, Geomorphology, 27, 75-92, 1999.

Bouillon, S., Korntheuer, M., Baeyens, W., and Dehairs, F.: A new automated setup for stable isotope analysis of dissolved organic carbon, Limnol. Oceanogr.-Meth., 4, 216-226, 2006.

Bouillon, S., Abril, G., Borges, A. V., Dehairs, F., Govers, G., Hughes, H. J., Merckx, R., Meysman, F. J. R., Nyunja, J., Osburn, C., and Middelburg, J. J.: Distribution, origin and cycling of carbon in the Tana River (Kenya): a dry season basin-scale survey from headwaters to the delta, Biogeosciences, 6, 2475-2493, doi:10.5194/bg-6-2475-2009, 2009.

Brunauer S., Emmett, P. H., and Teller, E.: Adsorption of Gases in Multimolecular Layers, J. Am. Chem. Soc., 60, 309-319, 1938.

Brown, T. and Schneider, H.: From plot to basin: the scale problem in studies of soil erosion and sediment yield, in: The Sustainable Management of Tropical Catchments, edited by: Harper, D. and Brown, T., John Wiley and Sons, Chichester, England, 1998.

Brunet, F., Dubois, K., Veizer, J., Nkoue Ndondo, G. R., Ndam Ngoupayou, J. R., Boeglin, J. L., and Probst, J. L.: Terrestrial and fluvial carbon fluxes in a tropical watershed: Nyong basin, Cameroon, Chem. Geol., 265, 563-572, 2009.

Cai, D. L., Tan, C. F., and Edmond, M. J.: Sources and transport of particulate organic carbon in the Amazon River and estuary, Estuar. Coast. Shelf S., 26, 1-14, 1988.

Cole, J. J. and Caraco, N. F.: Carbon in catchments: connecting terrestrial carbon losses with aquatic metabolism, Mar. Freshwater Res., 52, 101-110, 2001.

Cole, J. J., Prairie, Y. T., Caraco V, N. F., McDowell, W. H., Tranvik, L. J., Striegl, R. G., Duarte, C. M., Kortelainen, P., Downing, J. A., Middelburg, J. J., and Melack , J.: Plumbing the global carbon cycle: integrating inland waters into the terrestrial carbon budget, Ecosystems, 10, 171-184, 2007.

Couteaux, M. M., Sarmiento, L., Bottner, P., Acevedo, D., and Thiery, J. M.: Decomposition of standard plant material along an altitudinal transect (65-3968 m) in the tropical Andes, Soil Biol. Biochem., 34, 69-78, 2002.

Coynel, A., Seyler, P., Etcheber, H., Meybeck, M., and Orange, D.: Spatial and seasonal dynamics of total suspended sediment and organic carbon species in the Congo River, Global Biogeochem. Cy., 19, GB4019, doi:10.1029/2004GB002335, 2005. 
Dunne, T. and Ongweny, G. S. O.: A new estimate of sedimentation rates on the upper Tana River, The Kenyan Geographer, 2, 109126, 1976.

Finlay, J. C. and Kendall, C.: Stable isotope tracing of temporal and spatial variability in organic matter sources to freshwater ecosystems, in: Stable isotopes in ecology and environmental science, 2nd Edn., edited by: Michener, R. H. and Lajtha, K., Blackwell Publishing, Malden, USA, 283-333, 2007.

Gillson, L., Waldron, S., and Willis, K. J.: Interpretation of soil $\delta^{13} \mathrm{C}$ as an indicator of vegetation change in African savannas, J. Veg. Sci., 15, 339-350, 2004.

Hedges, J. I., Mayorga, E., Tsamakis, E., McClain, M. E., Aufdenkampe, A., Quay, P., and Richey, J. E.: Organic matter in Bolivian tributaries of the Amazon River: a comparison to the lower mainstream, Limnol. Oceanogr., 45, 1449-1466, 2000.

Hope, D. Billett M. F., and Cresser, M. S.: A review of the export of carbon in river water: Fluxes and processes, Environ. Pollut., 84, 301-324, 1994.

Houghton, A. R.: The Contemporary Carbon Cycle, in: Treatise on Geochemistry, edited by: Holland, H. D. and Turekian, K. K., Elsevier, Amsterdam, 8, 473-513, 2004.

Ittekkot, V.: Global trends in the nature of organic matter in river suspensions, Nature, 332, 436-438, 1988.

Ittekkot, V. and Laane, R. W. P. M.: Fate of riverine particulate organic matter, in: Biogeochemistry of Major World Rivers, edited by: Degens, E. T., Kempe, S., and Richey, J. E., John Wiley \& Sons, New York, 233-243, 1991.

Junk, W. J., Bayley, P. B., and Sparks, R. E.: The flood pulse concept in river-floodplain systems, in: Proceedings of the International large Rivers Symposium (LARS), edited by: Dodge, D. P., Canadian Special Publications of Fisheries and Aquatic Sciences, 106, 110-127, 1989.

Keil, R. G., Mayer, L. M., Quay, P. D., Richey, J. E., and Hedges, J. I.: Loss of organic matter from riverine particles in deltas, Geochim. Cosmochim. Ac, 61, 1507-1511, 1997.

Kendall, C., Silva, S. R., and Kelly, V. J.: Carbon and nitrogen isotopic compositions of particulate organic matter in four large river systems across the United States, Hydrol. Process., 15, 1301-1346, 2001.

Kitheka, J. U., Obiero, M., and Nthenge, P.: River discharge, sediment transport and exchange in the Tana estuary, Kenya, Estuar. Coast. Shelf S., 63, 455-468, 2005.

Kohn, J. M.: Carbon isotope compositions of terrestrial C3 plants as indicators of (paleo)ecology and (paleo)climate, P. Natl. Acad. Sci. USA, 107, 19691-19695, 2010.

Kunz, M. J., Anselmetti, F. S., Wüest, A., Wehrli, B., Vollenweider, A., Thüring, S., and Senn, D. B.: Sediment accumulation and carbon, nitrogen, and phosphorus deposition in the large tropical reservoir Lake Kariba (Zambia/Zimbabwe), J. Geophys. Res., 116, G03003, doi:10.1029/2010JG001538, 2011.

Lesack, L. F. W., Hecky, E. R., and Melack, J.: Transport of carbon, nitrogen, phosphorus and major solutes in Gambia River, West Africa, Limnol. Oceanogr., 29, 816-830, 1984.

Liu, H, Jacob, D. J., Bey, I., and Yantosca, R. M.: Constraints from ${ }^{210} \mathrm{~Pb}$ and ${ }^{7} \mathrm{Be}$ on wet deposition and transport in a global threedimensional chemical tracer model driven by assimilated meteorological fields, J. Geophys. Res., 106, 109-128, 2001.

Ludwig, W., Probst, J. L., and Kempe, S.: predicting the oceanic input of organic carbon by continental erosion, Global Bio- geochem. Cy., 10, 23-41, 1996.

Ludwig, W. and Probst, J. L.: River sediment discharge to the oceans: Present-day controls and global budgets, Am. J. Sci., 298, 265-295, 1998.

Maingi, J. K. and Marsh, S. E.: Quantifying hydrologic impacts following dam construction along the Tana River, Kenya, J. Arid Environ., 50, 53-79, 2002.

Martins, O.: Transport of carbon in the Niger River, in: Transport of Carbon and Minerals in: Major World Rivers, vol. 55, edited by: Degens, E. T., Kempe, S. and Soliman, H., Mitt. Geol.-Palont. Inst., Univ. Hamburg, Germany, 435-449, 1983.

Matisoff, G., Bonniwell, E. C., and Whiting, P. J.: Soil erosion and sediment sources in an Ohio watershed using Berillium-7, Cesium-137, and Lead-210, J. Environ. Qual., 31, 54-61, 2002.

Matisoff, G., Wilson, C. G., and Whiting, P. J.: The ${ }^{7} \mathrm{Be} /{ }^{210} \mathrm{~Pb}_{\mathrm{Xs}}$ ratio as an indicator or suspended sediment age or fraction of new sediment in suspension, Earth Surf. Processes, 30, 1191-1201, 2005.

Mayorga, E., Aufdenkampe, A. K., Masiello, C. A., Krusche, A. V., Hedges, J. I., Quay, P. D., Richey, J. E., and Brown, T. A.: Young organic matter as a source of carbon dioxide outgassing from Amazonian Rivers, Nature, 436, 538-541, 2005.

Mayorga, E., Seitzinger, S. P., Harrison, J. A., Dumont, E., Beusen, A. W., Bouwman, A. F., Fekete, B. M., Kroeze, C., and Van Drecht, G.: Global nutrient export from WaterSheds 2 (NEWS 2) : model development and implementation, Environ. Modell Softw., 25, 837-853, 2010.

Mayer, L. M.: Relationships between mineral surfaces and organic carbon concentrations in soils and sediments, Chem. Geol., 114, 347-363, 1994.

Meybeck, M.: Carbon, nitrogen, and phosphorus transport by world rivers, Am. J. Sci., 282, 401-450, 1982.

Meybeck, M.: Riverine transport of atmospheric carbon: Sources, global typology and budget, Water Air Soil Poll., 70, 443-463, 1993.

Middelburg, J. J. and Herman, P. J. M.: Organic matter processing in tidal estuaries, Mar. Chem., 106, 127-147, 2007.

Olsen, C. R., Larsen, I. L., Lowry, P. D., and Cutshall, N. H.: Geochemistry and deposition of ${ }^{7} \mathrm{Be}$ in river, estuarine and coastal waters, J. Geophys. Res., 91, 896-908, 1986.

Prentice, I. C, Farquah, M. J. R., Farham, M. J. R., Goulden, M. L., Heinmann, M., Jaramillo, V. J., Kherghi, H. S., Le Quere, C., Scholes, R. J., and Wallance, D. W. R.: The carbon cycle and atmospheric carbon dioxide, in: Climate change 2001: The Scientific Basis; Contribution of working group I to the 3rd assessment report of the IPCC, edited by: Houghton, J. T., Ding, Y., Griggs, D. J., Noguer, M., Linden, P. J. V. D., Dai, X., Maskell, K., and Johnson, C. A., Cambridge University Press, London, New York, 193-237, 2001.

Probst, J. L., Mortatti, J., and Tardy, Y.: Carbon river fluxes and weathering $\mathrm{CO}_{2}$ consumption in the Congo and Amazon river basins, Appl. Geochem., 9, 1-13, 1994.

Ralison, O., Dehairs, F., Middelburg, J. J., Borges, A. V., and Bouillon, S.: Carbon biogeochemistry in the Betsiboka estuary (northwestern Madagascar), Org. Geochem., 39, 1649-1658, 2008.

Rosgen, D. L.: A geomorphological approach to restoration of incised rivers, in: Proceedings of the Conference on Management of Landscapes Disturbed by Channel Incision, edited by: Wang, S. S. Y., Langendoen, E. J., and Shields Jr., F. D., Oxford Cam- 
pus, The University of Mississippi, 19-23 May 1997, 12-22, 1997.

Saari, H. K., Schmidt, S., Castain, P., Blanc, G., Sautour, B., Masson, O., and Cochran, J. K.: The particulate ${ }^{7} \mathrm{Be} /{ }^{210} \mathrm{~Pb}_{\mathrm{xs}}$ and ${ }^{234} \mathrm{Th} /{ }^{210} \mathrm{~Pb}$ xs activity ratios as tracers for tidal-to-seasonal particle dynamics in the Gironde estuary (France): Implications for the budget of particle-associated contaminants, Sci. Total Environ., 408, 4784-4794, 2010.

Sabine, C. L., Heimann, M., Artaxo, P., Bakker, D. C. E., Chen, C. T. A., Field, C. B., Gruber, N., Quere, C. L., Prinn, R. G., Richey, J. E., Lankao, P. R., Sathaye, J. A., and Valentini, R.: Current status and past trends of the global carbon cycle, in: The global carbon cycle: Integrating Humans, Climate and the Natural World, edited by: Field, C. B. and Raupach, M. R., Island Press, Washington, 17-44, 2004.

Schlünz, B. and Schneider, R. R.: Transport of terrestrial organic carbon to the oceans by rivers: re-estimating flux- and burial rates, Int. J. Earth Sci., 88, 599-606, 2000.

Schmidt, S., Howa, H., Mouret, A., Lombard, F., Anschutz, P., and Labeyrie, L.: Particle fluxes and recent sediment accumulation on the Aquitanian margin of Bay of Biscay, Cont. Shelf Res., 29, 1044-1052, 2009.

Scodanibbio, L. and Mañez, G.: The World Commission on Dams: a fundamental step towards integrated water resources management and poverty reduction? A pilot case in the Lower Zambezi, Mozambique, Phys. Chem. Earth, 30, 976-983, 2005.

Seyler, P., Etcheber, H., Orange, D., Laraque, A., Sigha-Nkamdjou, L., and Olivry, J. C.: Concentrations, fluctuations saisonnières et flux de carbonne dans le bassin du Congo, in: Colloque Grands Bassins Fluviaux peri Atlantiques: Congo, Niger, Amazone, edited by: Olivry, J. C. and Boulègue, J., ORSTOM, Paris, 217-228, 1995.

Sobek, S., Durisch-Kaiser, E., Zurbrügg, R., Wongfun, N., Wessels, M., Pasche, N., and Wehrli, B.: Organic carbon burial efficiency in lake sediments controlled by oxygen exposure time and sediment source, Limnol. Oceanogr., 54, 2243-2254, 2009.

Spencer, R. G. M., Hernes, P. J., Ruf, R., Baker, A., Dyda, R. Y., Stubbins, A., and Six, J.: Temporal controls on dissolved organic matter and lignin biogeochemistry in a pristine tropical river, Democratic Republic of Congo, J. Geophys. Res., 115, G03013, doi:10.1029/2009JG001180, 2010.

Spitzy, A. and Leenheer, J.: Dissolved organic carbon in rivers, in: Biogeochemistry of Major World Rivers, edited by: Degens, E. T., Kempe, S., and Richey, E. J., Scope 42, John Wiley \& Sons, New York, 1991.

Still, C. J. and Powell, R. L.: Continental-scale distributions of vegetation stable carbon isotope ratios, in: Isoscapes, edited by:
West, J. B., Bowen, G. J., Dawson, T. E., and Tu, K. P., Springer, Dordrecht, The Netherlands, 2010.

Syvitski, P. M. J., Vörösmarty, C. J., Albert, J., Kettner, J. A., and Green, P.: Impact of humans on the flux of terrestrial sediment to the global coastal ocean, Science, 308, 376-380, 2005.

Tieszen, L. L ., Senyimba, M. M., Imbamba, S. K., and Troughton, J. H.: The distribution of C3 and C4 grasses and carbon isotope discrimination along an altitudinal and moisture gradient in Kenya, Oecologia, 37, 337-350, 1979.

Thurman, E. M. (Ed.): Organic carbon in natural waters: amount, origin and clasification, in: Organic geochemistry of natural waters, Kluwer Academic Publishers Dordrecht, Netherlands, 5-65, 1985.

Townsend-Small, A., McClain, M. E., and Brandes, J. A.: Contributions of carbon and nitrogen from the Andes Mountains to the Amazon River: evidence from an elevational gradient of soils, plants, and river material, Limnol. Oceanogr., 50, 672-685, 2005.

Tranvik, L. J., Downing, J. A., Cotner, J. B., Loiselle, S. A., Striegl, R. G., Ballatore, T. J., Dillon, P., Finlay, K., Fortino, K., Knoll, L. B., Kortelainen, P. L., Kutser, T., Larsen, S., Laurion, I., Leech, D. M, McCallister, S. L., McKnight, D. M., Melack, J. M., Overholt, E., Porter, J. A., Prairie, Y., Renwick, W. H., Roland, F., Sherman, B. S., Schindler, D. W., Sobek, S., Tremblay, A., Vanni, M. J., Verschoor, A. M., von Wa-chenfeldt, E., and Weyhenmeyer, G. A.: Lakes and reservoirs as regulators of carbon cycling and climate, Limnol. Oceanogr., 54, 2298-2314, 2009.

Vannote, R. L., Minshall, G. W., Cummins, K. W., Sedell, J. R., and Cushing, C. E.: The river continuum concept, Can. J. Fish. Aquat. Sci., 37, 130-137, 1980.

Vörösmarty, C. J., Meybeck, M., Fekete, B., Sharma, K., Green, P., and Syvitski, J. P. M.: Anthropogenic sediment retention: major global impact from registered river impoundments, Glob. Planet. Change, 39, 169-190, 2003.

Ward, J. V. and Stanford, J. A.: The serial discontinuity concept of river ecosystems. In: Dynamics of lotic ecosystems, edited by: Fontaine, T. D. and Bartell, S. M, Ann Arbor Science Publications, Ann Arbor, Michigan, 29-42, 1983.

Whiting, P. J., Matisoff, G., Fornes, W., and Soster, F. M.: Suspended sediment sources and transport distance in the Yellowstone River basin, Geol. Soc. Am. Bull., 117, 515-529, 2005.

Wooller, J. M., Swain, L. D., Street-Perrott, F. A., Mathai, S., and Agnew, Q. D. A.: An altitudinal and stable carbon isotope survey of C3 and C4 graminoids on Mount Kenya, Journal of East African Natural History, 90, 69-85, 2001.

Wynn, J. G. and Bird, M. I.: C4-derived soil organic carbon decomposes faster than its $\mathrm{C} 3$ counterpart in mixed $\mathrm{C} 3 / \mathrm{C} 4$ soils, Glob. Change Biol., 13, 2206-2217, 2007. 